\title{
Growth substrate induced functional changes elucidated by FTIR and Raman spectroscopy in in-vitro cultured human keratinocytes.
}

Aidan Meade

Technological University Dublin, aidan.meade@tudublin.ie

Fiona Lyng

Technological University Dublin, fiona.lyng@tudublin.ie

Peter Knief

Technological University Dublin

See next page for additional authors

Follow this and additional works at: https://arrow.tudublin.ie/radart

Part of the Physics Commons

\section{Recommended Citation}

Meade, A. et al. (2007) Growth substrate induced functional changes elucidated by FTIR and Raman spectroscopy in in-vitro cultured human keratinocytes. Analytical and Bioanalytical Chemistry, vol. 387, no.5, pp.1717-1728. doi:10.1007/s00216-006-0876-5

This Article is brought to you for free and open access by the Radiation and Environmental Science Centre at ARROW@TU Dublin. It has been accepted for inclusion in Articles by an authorized administrator of ARROW@TU Dublin. For more information, please contact arrow.admin@tudublin.ie, aisling.coyne@tudublin.ie, gerard.connolly@tudublin.ie.

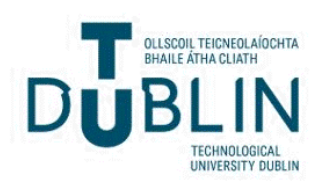


Authors

Aidan Meade, Fiona Lyng, Peter Knief, and Hugh Byrne

This article is available at ARROW@TU Dublin: https://arrow.tudublin.ie/radart/6 


\title{
Growth substrate induced functional changes elucidated by FTIR and Raman spectroscopy in in-vitro cultured human keratinocytes
}

\author{
Aidan D. MeAde ${ }^{1,2}$, Fiona M. LynG ${ }^{2}$, Peter KnieF ${ }^{3}$ And Hugh J. Byrne ${ }^{3}$ \\ 1. School of Physics, Faculty of Science, Dublin Institute of Technology, Kevin Street, Dublin \\ 8, Ireland. \\ 2. Radiation and Environmental Science Centre, Focas Institute, Dublin Institute of \\ Technology, Camden Row, Dublin 8, Ireland. \\ 3. Focas Institute, Dublin Institute of Technology, Camden Row, Dublin 8, Ireland. \\ Tel.: 00353-1-4024691; \\ e-mail: aidan.meade@dit.ie
}

\begin{abstract}
Non-invasive measurements of cellular function in in-vitro cultured cell lines using vibrational spectroscopy require the use of spectroscopic substrates such as quartz, $\mathrm{ZnSe}$ and MirrIR etc. These substrates are generally dissimilar to the original in-vivo extracellular environment of a given cell line and are often tolerated poorly by cultured cell lines resulting in morphological and functional changes in the cell. The present study demonstrates various correlations between vibrational spectroscopic analyses and biochemical analyses in the evaluation of the interaction of a normal human epithelial keratinocyte cell line (HaCaT) with MirrIR and quartz substrates coated with fibronectin, laminin and gelatin. The findings of this study suggest that there is a correlation between quantitative measurements of cellular proliferative capacity and viability and peak area ratios in FTIR spectra, with replicated differences in similar areas of the observed Raman spectra. Differences in the physiology of cells were observed between the two spectroscopic substrates coated in fibronectin and laminin, but little differences were observed when the cells were attached to gelatin coated quartz and MirrIR slides. The correlations demonstrate the sensitivity of the spectroscopic techniques to evaluate the physiology of the system. Furthermore the study suggests that gelatin is a suitable coating for use in spectroscopic measurements of cellular function in human keratinocytes, as it provides a material that normalises the effect of substrate attachment on cellular physiology. This effect is likely to be cell-line dependent, and it is recommended that similar evaluations of this effect are performed for those combinations of spectroscopic substrate and cell lines that are to be used in individual experiments.
\end{abstract}

Keywords: Raman/FTIR Spectroscopy, HaCaT keratinocytes, adhesion effects, spectroscopic substrates 


\section{Introduction}

Vibrational biospectroscopy has advanced considerably in recent years, with attention moving from a focus on measurement of the morphology of cellular and tissue species, to, recently, analyses of the relationship between the biochemical content of biological species and the functionality of such species. At present Fourier Transform Infrared Microspectrosopy (FTIRM) and Confocal Raman Microspectroscopy (CRM) have identified in-situ molecular alterations associated with cell death via apoptosis [1-3] or necrosis [4, 5], or as a result of proliferative changes in cellular activity [6-8] or mitosis [9]. It has also been shown that these modalities can identify molecular changes associated with changes in the phenotype of differentiating embryonic cells [10, 11]. A key characteristic of both CRM and FTIRM is their potential to provide non-invasive information on the total, spatially resolved, molecular composition of the sample, without the need for the introduction of extraneous chemical markers into the cell. It has been established that FTIRM is non-toxic to live cells, even at the increased levels of power utilised in Synchrotron Radiation Fourier Transform Infrared Microspectroscopy (SRFTIRM) [12]. CRM, however, has been shown to result in photoinduced effects when visible excitation wavelengths are utilised [13-15] as compared to when wavelengths in the Near IR and IR are utilised (i.e. 785nm and above) [13] with live cell cultures. No such effects have been observed to date with the use of CRM applied to chemically fixed cellular species, however.

It is known that biomaterial surfaces effect significant responses in the cell, but the underlying molecular mechanisms generating these responses remain poorly understood [16]. Noninvasive spectroscopic measurements of cellular function in in-vitro cultured cell lines require substrates such as quartz, $\mathrm{ZnSe}$ and MirrIR $\left(\mathrm{Ag} / \mathrm{SnO}_{2}\right.$ coated glass for FTIRM from Kevley Technologies) etc. It has been demonstrated that surfaces and scaffolds for cell culture can induce changes in cellular adhesion and motility [17, 18], in their proliferation and differentiation [16, 19], and in gene expression [20], ultimately influencing the fate of the cell [21]. Much of the interaction of adherent cells with their culture substrates is dependent on the surface chemistry [18, 22] and surface energy [23]. When substrates are coated with biocompatible molecules to effect or enhance cellular proliferation, the conformation of the molecule has also been shown to produce changes in the level of response [19]. 
In this study vibrational spectroscopy is employed to evaluate the physiology of human keratinocyte cell cultures on MirrIR and quartz, which are coated with biocompatible molecules. The spectroscopic data are correlated with both standard absorbance and fluorescence assays as measures of the viability and proliferative capacity of the cells on these coated substrates. The study thus aims to both demonstrate the efficacy of the spectroscopic techniques to evaluate the physiology of the system, and to evaluate the optimum substrates for cell growth for spectroscopic studies. 


\section{Methods}

\subsection{Cell Culture and Sample Preparation}

A spontaneously immortalized human epithelial keratinocyte cell line ( $\mathrm{HaCaT})$ derived from adult skin was used throughout this work. They are normal, non-tumourigenic and p53 mutated adult keratinocytes. The cells are polygonal, of approximately $20 \mu \mathrm{m}$ diameter, producing a 'cobblestone' appearance in culture [24]. HaCaT cells were cultured in Dulbecco's MEM: F12 (1:1) medium (Sigma, Dorset, U.K.) containing 10\% fetal calf serum (Gibco, Irvine, U.K.) 1\% penicillin-streptomycin solution 1000 IU (Gibco, Irvine, U.K.), $2 \mathrm{mM}$ L- glutamine (Gibco, Irvine, U.K.) and $1 \mu \mathrm{g} / \mathrm{ml}$ hydrocortisone (Sigma, Dorset, U.K.). Cells were maintained in an incubator at $37^{\circ} \mathrm{C}$, with $95 \%$ humidity and $5 \% \mathrm{CO}_{2}$. Subculture was routinely performed when cells were $80-100 \%$ confluent, using a $1: 1$ solution of $0.25 \%$ trypsin and $1 \mathrm{mM}$ versene at $37^{\circ} \mathrm{C}$.

The present work was performed to evaluate $\mathrm{HaCaT}$ cell adhesion to three substrate coatings, fibronectin, laminin and gelatin. Fibronectin is a large multidomain glycoprotein that is found throughout connective tissue, on the surface of cells and within bodily fluids. It facilitates cell adhesion through binding to integrin receptors on the cell surface, subsequently producing regulation of genetic responses in the cell and influencing cell growth and differentiation [25]. Laminin is also a heterotrimeric glycoprotein [26], which facilitates cell adhesion in a similar manner, though it binds to a different set of cellular integrins. Gelatin is a protein by-product of the thermal denaturation of collagen [27, 28].

HaCaT cells were loaded at a concentration of $1 \times 10^{5}$ cells per substrate onto MirrIR (Kevley Technologies, Inc.) and quartz (UQG Optics Ltd.) substrates both uncoated and coated in fibronectin $\left(1 \mu \mathrm{g} / \mathrm{ml}\right.$ solution in PBS; from human plasma), gelatin $\left(2 \%\right.$ in $\mathrm{dH}_{2} \mathrm{O}$; type $\mathrm{B}$ from bovine skin), and laminin $(10 \mu \mathrm{g} / \mathrm{ml}$ from Engelbreth-Holm-Swarm murine sarcoma). All coating materials were purchased from Sigma-Aldrich and used without further purification. MirrIR slides were cut into $20 \times 25 \mathrm{~mm}$ pieces, sterilised in ethanol and dried in a laminar flow hood before coating with the substrate molecules. Both spectroscopic substrates were coated in approximately $300 \mu$ of the coatings. 
Spectroscopic substrates were incubated for 24 hours at $4^{\mathrm{O}} \mathrm{C}$ in the gelatin solution, for 4 hours at room temperature in the laminin solution, and for $40 \mathrm{mins}$ at room temperature in the collagen and fibronectin solution. The solutions were aspirated from the fibronectin and laminin coated substrates and washed in PBS before deposition of the cell suspension. The solution was aspirated from the gelatin coated spectroscopic substrates and the cell suspension deposited immediately. Cells were cultured on these growth substrates for 3 days before subsequent spectroscopic and fluorescence/absorbance assays. At 3 days, the cells were fixed in $4 \%$ formalin in PBS for Raman and FTIR analysis. They were washed in $\mathrm{dH}_{2} \mathrm{O}$ and stored in $\mathrm{dH}_{2} \mathrm{O}$ at $4^{\mathrm{O}} \mathrm{C}$ for subsequent Raman analysis and in a dessicator until subsequent FTIR analysis.

The fluorescence and absorbance assays were averaged over two independent experiments $(n=2)$, with 3 and 9 replicates per experiment, respectively. Spectroscopic measurements were taken from one experiment performed in triplicate. Control samples are those in which cells are plated directly onto the uncoated spectroscopic substrate. 


\subsection{Fluorescence and Absorbance Assays}

Parallel cultures were prepared in 6-well plates for spectroscopic assay and investigation of biochemical activity (via measures of proliferative capacity (Alamar Blue fluorescence), lysosomal activity (Neutral Red fluorescence) and protein content (Coomassie Blue absorbance)). Each assay utilised a Tecan Genios microplate reader, with a $5 \times 5$ matrix of 25 measurements taken for each well of the 6 well plates to minimize point-to-point variations in fluorescent or absorbance activity. The final fluorescence or absorbance measurement was an average of each of the 25 measurements.

Alamar Blue (AB) is a resazurin dye [29] (dark blue, non-fluorescent) which is reduced to resorufin (pink and highly fluorescent) through a redox reaction, the level of which is indicative of cellular proliferation [29, 30]. Throughout this study, the pink, fluorescent molecule resorufin was excited at $540 \mathrm{~nm}$ and the fluorescence read at $595 \mathrm{~nm}$. AB was added to the HaCaT cells in DMEM F-12 (15.6 g/L; Sigma-Aldrich) which did not contain phenol red (as this interferes with the fluorescence of resorufin) and $\mathrm{NaHCO}_{3}(1.2 \mathrm{~g} / \mathrm{L})$ giving a $\mathrm{pH}$ of $6.9 \pm 0.2$. Neutral Red (NR; 3-Amino-7-dimethylamino-2-methyl-phenazine hydrochloride) is a supravital fluorescent dye which is weakly cationic and can diffuse across the cellular membrane, accumulating in cellular lysosomes [31-33]. Increases in cell wall permeability and lysosome fragility are associated with the latter stages of cell death, thus the level of accumulation of NR in the cell is indicative of the level of viability in a sample of cells. Neutral Red stock solution was prepared using $0.5 \mathrm{mg}$ of NR dye in $100 \mathrm{ml}$ DMEM-F12 minus phenol red indicator [31-33].

The $\mathrm{AB} / \mathrm{NR}$ working solution was prepared using $5 \% \mathrm{AB}$ and $1.25 \%$ of the NR stock in DMEM-F12 minus phenol red. A range finding study found that a reasonable incubation time with this solution was 1.5 hours (figure 1), and that no quenching of fluorescence was observed when cells were incubated in a mixture of $A B / N R$. Samples were therefore incubated with $2.5 \mathrm{ml}$ of the $\mathrm{AB} / \mathrm{NR}$ solution at $37^{\circ} \mathrm{C}$ for 1.5 hours, at which point the $\mathrm{AB}$ fluorescence was measured. Samples were then washed once in $2.5 \mathrm{ml}$ PBS and $2.5 \mathrm{ml}$ of a fixative solution containing $1 \%$ glacial acetic acid and $50 \%$ ethanol in $\mathrm{dH}_{2} \mathrm{O}$, to lyse the cell 
and release the NR dye. Cells were then shaken at $240 \mathrm{rpm}$ for $30 \mathrm{mins}$ and fluorescence was read at $650 \mathrm{~nm}$ after excitation at $540 \mathrm{~nm}$ [31-33].

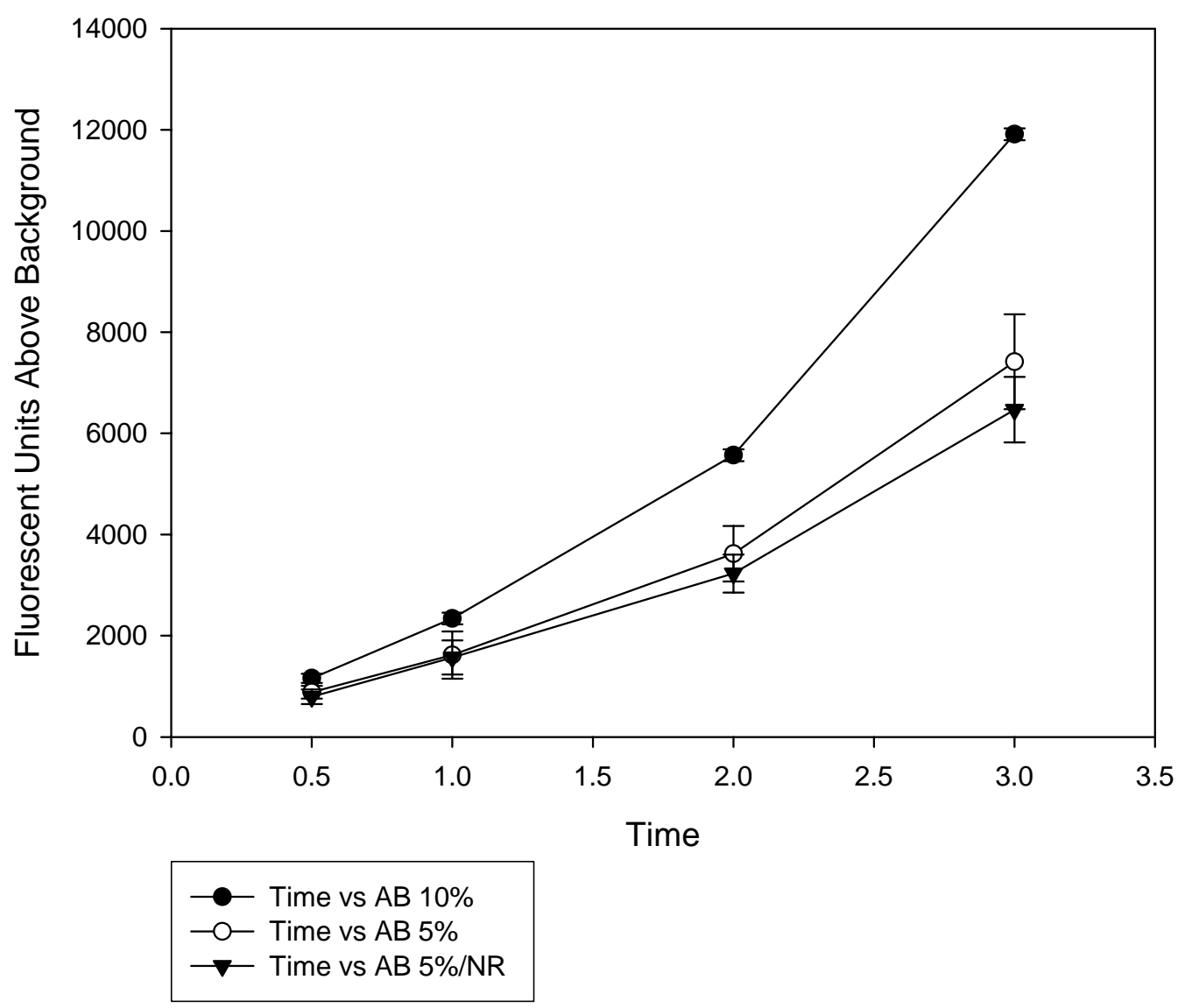

Figure 1. Optimisation of AB Fluorescence Assay

Commassie Blue is a dye which binds to protein within the lysed cell [34]. After binding, and subsequent washing to remove unbound Coomassie Blue, it is possible then to quantify via measurement of absorbance at $595 \mathrm{~nm}$ (with a reference absorbance measurement at $340 \mathrm{~nm}$ ) the total protein content within the cell [35, 36]. In the present work, after the NR fluorescence had been measured, the samples were washed once in $2.5 \mathrm{mls}$ of the fixative solution, $2.5 \mathrm{mls}$ of the Coomassie Blue solution was then added as per Liebsch and Spielmann [35], samples were shaken for $10 \mathrm{mins}$ at $240 \mathrm{rpm}$ and subsequently washed twice in a washing solution (10\% ethanol, $5 \%$ glacial acetic acid, $85 \%$ distilled water), with another shaking step for 10 minutes on the second wash. Finally $2.5 \mathrm{mls}$ of a measuring solution $(1 \mathrm{M}$ Potassium Acetate in 70\% ethanol and 30\% distilled water) was added and the samples were shaken in this solution for 10 minutes at $240 \mathrm{rpm}$. At this point the absorbance of the samples was measured at the wavelengths above. 


\subsection{Spectroscopic Assays}

\subsubsection{Raman Spectroscopic Measurements}

An Instruments S.A. (Jobin-Yvon) Labram 1B spectrometer was used throughout this work, which is fed by an external Argon-Ion laser operating at $514.5 \mathrm{~nm}$. Throughout the measurements, a x100 objective was employed which gave a spatial resolution of $\sim 1 \mu \mathrm{m}$ at the sample. The system was pre-calibrated to the $520.7 \mathrm{~cm}^{-1}$ spectral line of Silicon. The laser power at the objective focus was found to be $15 \mathrm{~mW}$. The Labram system is a confocal spectrometer that contains two interchangeable gratings $(600$ and 1800 lines $/ \mathrm{mm}$ respectively). In the following experiments the 1800 lines/mm grating was used, which gave a spectral resolution of around $1 \mathrm{~cm}^{-1}$ per pixel. The backscattered Raman signal was integrated for 120 seconds over the spectral ranges from 400 to 1900 and 2500 to $3600 \mathrm{~cm}^{-1}$ with respect to the excitation frequency. The detector used was a 16-bit dynamic range CCD detector which is Peltier cooled. Images of the sample were acquired using a video camera within the system.

Spectra were recorded from the cellular nucleus, with 45 spectra recorded per substrate and averaged. A quartz background spectrum was acquired for each individual quartz coverslip used, and subsequently subtracted before averaging. A simple baseline subtraction was performed in Matlab. A Savitsky-Golay filter ( $5^{\text {th }}$ order, 17 points) was used to smooth spectra. Band assignments were based on the data in table 1, which is taken from numerous publications and reviews [37-41]. 


\begin{tabular}{|c|c|}
\hline Wavenumber $\left(\mathrm{cm}^{-1}\right)$ & Assignment \\
\hline 3070 & Amide $\mathrm{B}(\mathrm{CNH}$ bend $)$ \\
\hline 2960 & $\mathrm{CH}_{3}$ stretch (antisymmetric) due to methyl terminal of membrane phospholipids \\
\hline 2936 & $\mathrm{CH}_{3}$ stretch \\
\hline 2928 & $\mathrm{CH}_{2}$ antisymmetric stretch of Methylene group of membrane phospholipids \\
\hline 2886 & $\mathrm{CH}_{2}$ stretch (symmetric) due to methylene groups of membrane phospholipids \\
\hline 2854 & $\mathrm{CH}_{2}$ stretch \\
\hline 2739 & $\mathrm{CH}$ stretch \\
\hline 1736 & $\mathrm{C}=\mathrm{O}$ stretch \\
\hline $1667 ; 1640$ & Amide I (protein) $\mathrm{C}=\mathrm{O}$ stretching of amide coupled to $\mathrm{NH}_{2}$ in-plane bending \\
\hline 1657,1659 & $\mathrm{C}=\mathrm{C}$ stretch (lipids), Amide I ( $\alpha$-helix, protein) \\
\hline 1611 & Tyr (aromatics) \\
\hline 1566 & Phe, Trp (phenyl, aromatics) \\
\hline 1550 & Amide II absorption due to $\mathrm{N}-\mathrm{H}$ bending coupled to a C-N stretch \\
\hline 1509 & $\mathrm{C}=\mathrm{C}$ stretch (aromatics) \\
\hline 1452 & $\mathrm{CH}_{2}$ stretch deformation of methylene group (lipids) \\
\hline 1439 & $\mathrm{CH}_{2}$ def. \\
\hline 1420 & $\mathrm{CH}_{3}$ asymmetric stretch (lipids, aromatics) \\
\hline 1397 & $\mathrm{CH}_{3}$ bending due to methyl bond in the membrane \\
\hline 1382 & $\mathrm{COO}^{-}$symmetric stretch \\
\hline 1367 & $\mathrm{CH}_{3}$ symmetric stretch \\
\hline 1336 & Adenine, Phenylalanine, $\mathrm{CH}$ deformation \\
\hline 1304 & Lipids $\mathrm{CH}_{2}$ twist, protein amide III band, adenine, cytosine \\
\hline 1267 & Amide III ( $\alpha$-helix, protein) \\
\hline 1250 & Amide III ( $\beta$-sheet, protein $)$ \\
\hline 1235 & Antisymmetric phosphate stretching \\
\hline 1206 & $\mathrm{C}-\mathrm{C}$ stretch, $\mathrm{C}-\mathrm{H}$ bend \\
\hline 1165 & $\mathrm{C}-\mathrm{O}$ stretch, $\mathrm{COH}$ bend \\
\hline 1130 & $\mathrm{C}-\mathrm{C}$ asymmetric stretch \\
\hline $1100,1094,1081$ & $\mathrm{PO}_{2}^{-}$symmetric stretch (nucleic acids) \\
\hline 1065 & Chain C-C \\
\hline 1056 & RNA ribose $\mathrm{C}-\mathrm{O}$ vibration \\
\hline 1003 & Phenylalanine (ring-breathing) \\
\hline 967 & $\mathrm{C}-\mathrm{C}$ and $\mathrm{C}-\mathrm{N}$ stretch $\mathrm{PO}_{3}{ }^{2-}$ stretch (DNA) \\
\hline 957 & $\mathrm{CH}_{3}$ deformation (lipid, protein) \\
\hline 936 & $\mathrm{C}-\mathrm{C}$ residue $\alpha$-helix \\
\hline 921 & C-C stretch proline \\
\hline 898 & $\mathrm{C}-\mathrm{C}$ stretch residue \\
\hline 870 & C-DNA \\
\hline 853 & Ring breathing Tyr $-\mathrm{C}-\mathrm{C}$ stretch proline \\
\hline 828,833 & Out of plane breathing Tyr; $\mathrm{PO}_{2}^{-}$asymmetric stretch DNA (B-form) \\
\hline 807 & A-DNA \\
\hline 786 & DNA - RNA $\left(\mathrm{PO}_{2}^{-}\right)$symmetric stretching \\
\hline 746 & Thymine \\
\hline 727 & Adenine \\
\hline
\end{tabular}

Table 1. Peak assignments derived from Krishna et al [37], Nijssen et al [38], Synytsya et al [39], Edwards and Carter [40], and Puppels et al [41] (and references therein)

\subsubsection{FTIR Spectroscopic Measurements}

FTIRM was performed using a Perkin Elmer GX-II spectrometer. The system is equipped with a Mid-infrared source with mid-infrared and far-infrared beam splitters that allow spectroscopic measurements of wavenumber shifts in the range 7000 to $50 \mathrm{~cm}^{-1}$ with a maximum resolution of $0.3 \mathrm{~cm}^{-1}$. The system is also equipped with a microscope attachment containing a 40 objective, and is configured with the AutoIMAGE microscope system that 
can operate in transmission or reflectance modes. All microscope operations including adjustments to aperture, focus and illumination are fully automated and controlled from an attached PC. The system includes a built-in $35 \mathrm{~W}$ tungsten halogen illuminator, a motorised stage and a CCD video camera. The FTIRM measurements reported here utilised aperture sizes of $100 \times 100 \mu \mathrm{m}$, spectral resolution of $4 \mathrm{~cm}^{-1}$, with 64 scans per spectrum. All spectra were acquired in reflection mode, effectively a double transmission after reflection from the broadband MirrIR substrate, with 250 spectra recorded from each sample. The final baseline corrected spectrum from each sample was an average of each of these measurements. IR band assignments as shown in table 2 were employed throughout the study.

\begin{tabular}{|c|c|}
\hline Wavenumber $\left(\mathrm{cm}^{-1}\right)$ & Assignment \\
\hline 3328 & Amide A $(v-N-H)$, proteins \\
\hline 3129 & Amide B $(v-\mathrm{N}-\mathrm{H})$, proteins \\
\hline 3015 & $v=\mathrm{C}-\mathrm{H}$, lipids \\
\hline 2960 & $v$ as $-\mathrm{CH}_{3}$, lipids proteins \\
\hline 2920 & $v$ as $-\mathrm{CH}_{3}$, lipids proteins \\
\hline 2875 & $v \mathrm{~s}-\mathrm{CH}_{3}$, lipids proteins \\
\hline 2850 & $v \mathrm{~s}-\mathrm{CH}_{2}$, lipids proteins \\
\hline $1720-1745$ & $v-\mathrm{C}=\mathrm{O}$, lipids (esters) \\
\hline $1710-1716$ & $v$ as $-\mathrm{C}=\mathrm{O}$, RNA (esters) \\
\hline $1705-1690$ & $v$ as $-\mathrm{C}=\mathrm{O}, \mathrm{RNA}, \mathrm{DNA}$ \\
\hline 1654 & Amide I $v-\mathrm{C}=\mathrm{O}(80 \%), v-\mathrm{C}-\mathrm{N}(10 \%), \delta-\mathrm{N}-\mathrm{H}(10 \%), \alpha$-helix \\
\hline $1630-1640$ & Amide I $v-\mathrm{C}=\mathrm{O}(80 \%), v-\mathrm{C}-\mathrm{N}(10 \%), \delta-\mathrm{N}-\mathrm{H}(10 \%), \beta$-structure \\
\hline 1610,1578 & $v-\mathrm{C} 4-\mathrm{C} 5, v-\mathrm{C}=\mathrm{N}$, imidazole ring, DNA, RNA \\
\hline 1515 & Aromatic tyrosine ring (Lasch et al) \\
\hline $1540-1550$ & Amide II $\delta$-N-H (60\%), $v$ - C-N (40\%), $\alpha$-helix \\
\hline 1530 & Amide II $\delta$-N-H $(60 \%), v-\mathrm{C}-\mathrm{N}(40 \%), \beta$-structure \\
\hline 1467 & $\delta-\mathrm{CH}_{2}$ lipids, proteins \\
\hline 1455 & $\delta$ as $-\mathrm{CH}_{3} /-\mathrm{CH}_{2}$ scissoring lipids, proteins \\
\hline $1370-1400$ & $v-\mathrm{COO}^{-}, \delta \mathrm{s}-\mathrm{CH}_{3}$ lipids, proteins \\
\hline $1330-1200$ & Amide III, proteins \\
\hline $1230-1244$ & $v$ as $-\mathrm{PO}_{2}^{-}, \mathrm{RNA}, \mathrm{DNA}$ \\
\hline 1160,1120 & $v-\mathrm{C}-\mathrm{O}, \mathrm{RNA}$ ribose \\
\hline 1170,1070 & $v$ as, $v$ s - CO-O-C, lipids \\
\hline $1090-1084$ & $v \mathrm{~s}-\mathrm{PO}_{2}^{-}, \mathrm{RNA}, \mathrm{DNA}$ \\
\hline 1060,1050 & $v-\mathrm{C}-\mathrm{O}$, deoxyribose/ribose DNA, RNA \\
\hline 996 & RNA stretch and bend ring of uracyl \\
\hline 965 & symmetric $\mathrm{PO}_{4}^{-}$stretch (DNA) and deoxyribose-phosphate skeletal motions \\
\hline
\end{tabular}

Table 2. IR Peak assignments (for cellular spectra) derived from Gault et al, [42-44] and Zellmer et al [45] (and references therein). 


\section{Results and Discussion}

\subsection{FluorescencelAbsorbance Assays}

The results of fluorescence and absorbance measurements of cellular proliferation, viability and total protein content are presented in figures 2-4. All measurements have been normalised to the MirrIR control. Error bars depict the variability at one standard error on the mean of the measurements.

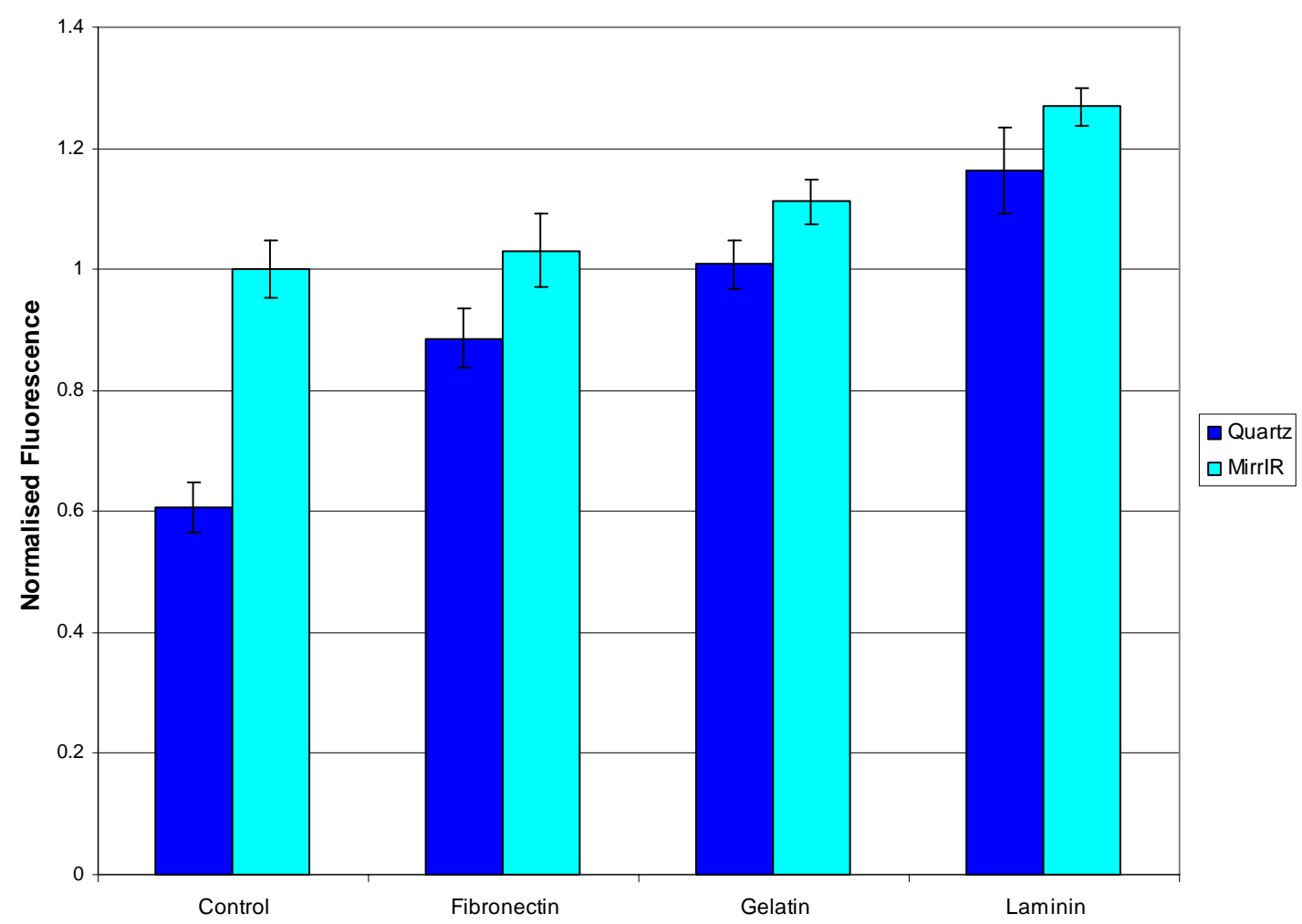

Figure 2. Alamar Blue Fluorescence by substrate (Normalised to MirrIR Control for both MirrIR Substrate and Quartz Substrate) . 


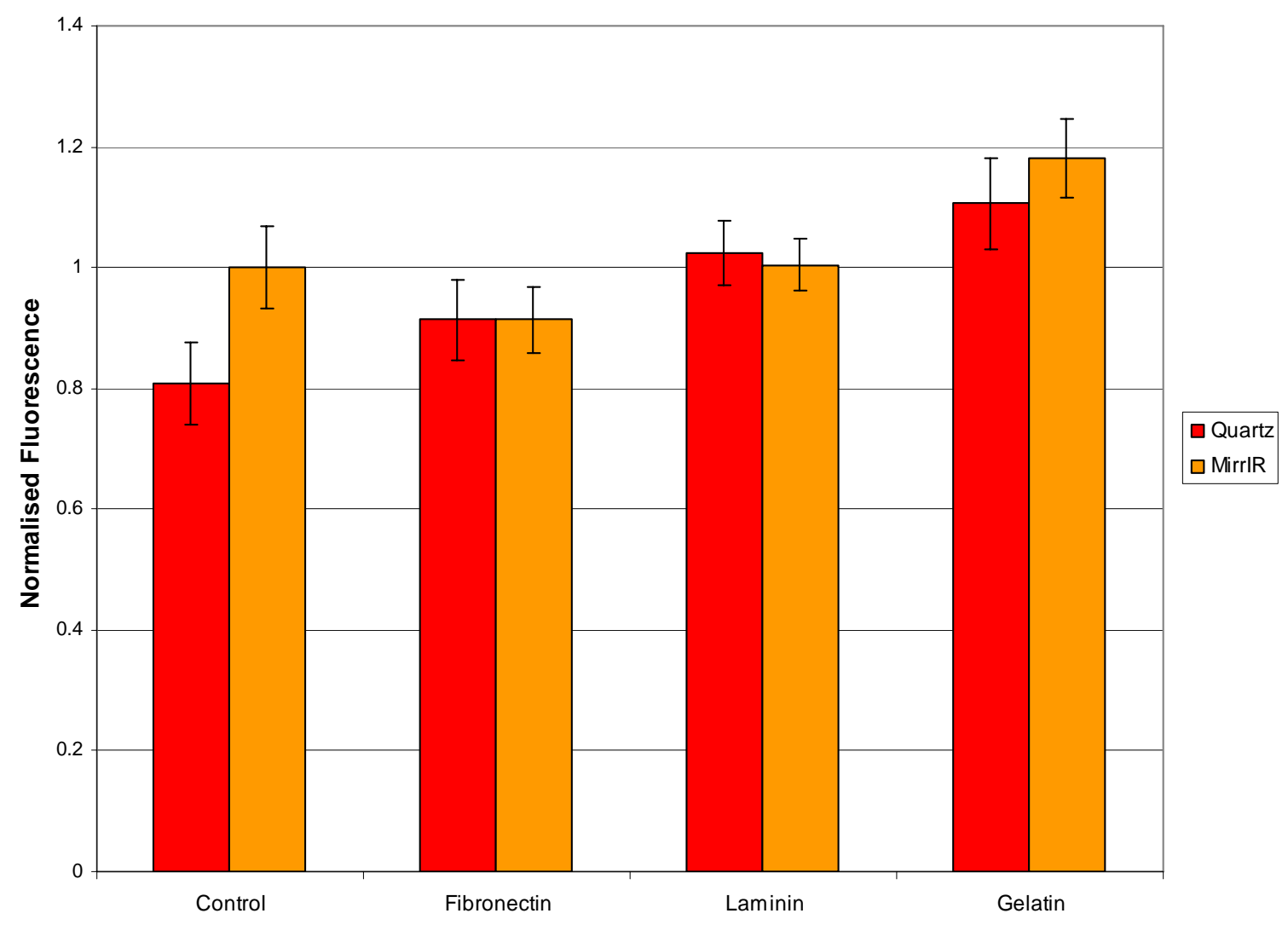

Figure 3. Neutral Red Fluorescence by substrate (Normalised to MirrIR Control for both MirrIR Substrate and Quartz Substrate). 


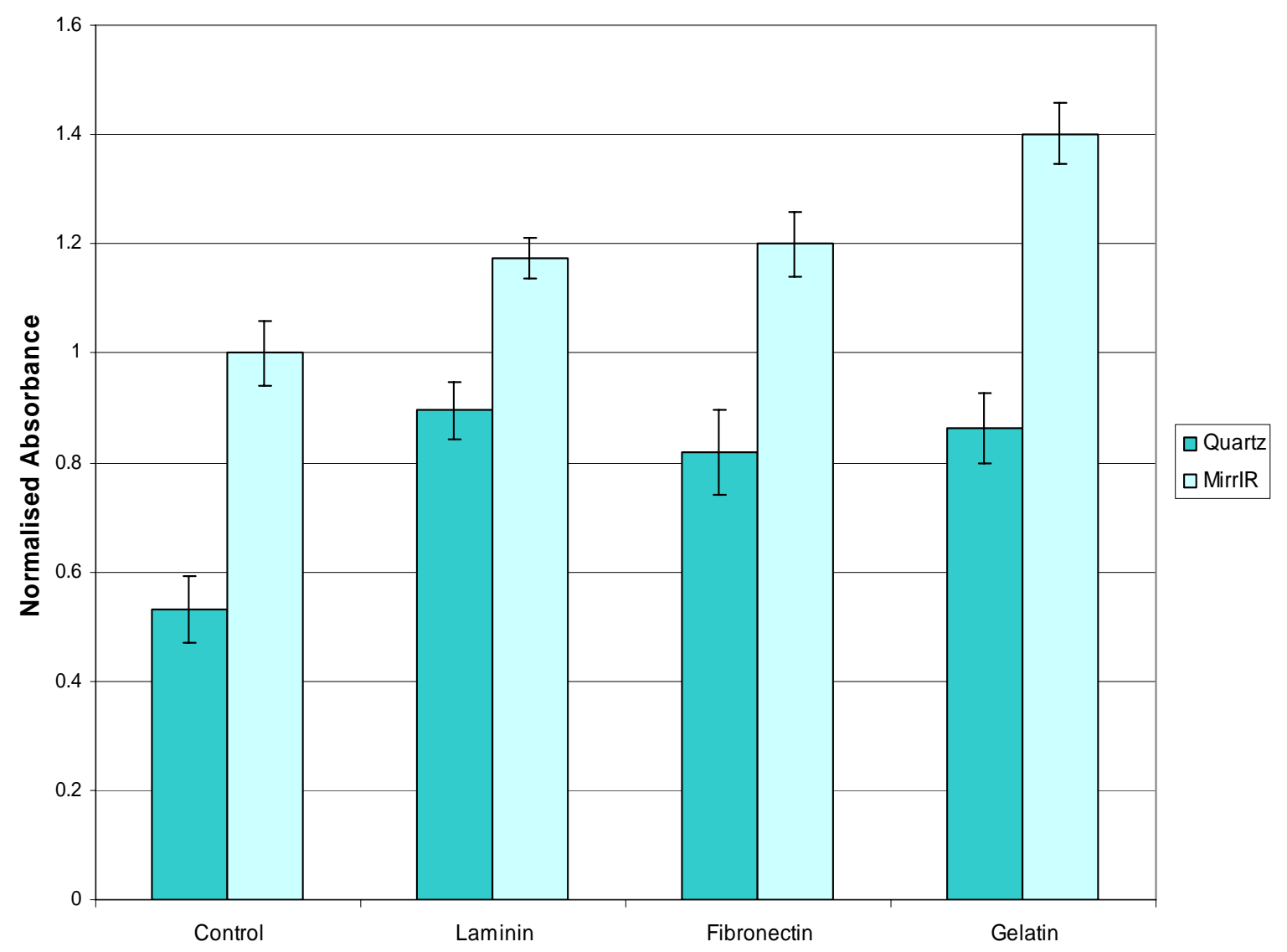

Figure 4. Coomassie Blue Absorbance by substrate (Normalised to MirrIR Control for both MirrIR Substrate and Quartz Substrate).

The general trend in the fluorescence measurements indicates that cellular proliferation, viability and protein content are enhanced by growth of $\mathrm{HaCaT}$ keratinocytes on gelatin, fibronectin and laminin. It appears that uncoated quartz induces a marked decrease in cellular proliferation and protein content. The enhancement in proliferation and viability is more pronounced when cells are grown on coated quartz substrates than MirrlR substrates, demonstrating that molecular conformation plays a role in cellular physiology post attachment as shown previously [19]. This also indicates that the $\mathrm{Ag} / \mathrm{SnO}_{2}$ coating on the reflective surface of MirrIR substrates plays some role in promotion of cellular attachment, which may be as a result of surface roughness on the nanometer scale [46-48].

The adhesion of cells to the extracellular matrix (ECM) is mediated by integrin binding [25]. Integrins are cell surface receptor proteins which bind the ECM to the cytoskeletal proteins within the cell, which subsequently stimulates the production and regulation of signalling proteins, such as protein kinase C and EGF [49, 50]. This ultimately results in increasing 
proliferation and motility, which is also dependent on the charge distribution presented by the ECM coating molecule to the adhering cell $[18-23,25]$. Ultimately the reaction of the cell to such influences are complex, being the cumulative effect of the increased or decreased regulation of a number of stimulatory pathways in the cell, with the end physiological change in any given cell being dependent on the cell and substrate ECM [50, 51]. It has been shown that adhesion of epithelial keratinocytes to fibronectin, collagen I and laminin promotes the activation of EGFR, although this effect can be sustained for various periods of time depending on the ECM molecule [50]. Bearing in mind that this effect is augmented by the conformation of the ECM molecule and its surface charge distribution, it is possible to suggest that the results of the present work (figure 2) indicate increased sustained production of signalling proteins resulting in increased proliferation of keratinocytes cultured on fibronectin, laminin and gelatin coated quartz slides, but only MirrIR slides coated with laminin produce significant changes in keratinocyte proliferation relative to the control. Figure 3 suggests that significant increases in cellular viability, relative to the control, are observed in keratinocytes grown on quartz coated with laminin and gelatin, but only significant increases in viability are observed when keratinocytes are grown on gelatin coated MirrIR slides. Taken together, both these results suggest that a coating such as gelatin provides an ECM that maintains similar proliferation effects on both quartz and MirrIR substrates, while increasing viability, which may be desirable for long-term cultures. Increases in protein content (which are seen as the result of increases in proliferation [6,8 and references therein]) shown in figure 4 may be normalised for spectroscopic purposes by normalising spectra to the Amide I band and/or the $\mathrm{CH}$ peak at $2939 \mathrm{~cm}^{-1}$ (in the case of Raman spectra) and $3328 \mathrm{~cm}^{-1}$ (in the case of FTIR spectra).

Although the measurements here concentrate on one adherent cell line (HaCaT keratinocyte), the adherent effects likely to occur in other cell lines can be speculated from existing research. It is known that the chemistry of the substrate modifies integrin receptor binding and through this cellular proliferation, viability and motility. Doornaert et al [52] have examined the effect of collagen, fibronectin and laminin on human bronchial epithelial cell (HBE) proliferation where similar relationships between substrates have been found as have been observed in the present work. Keselowsky et al [16] have observed hydroxyapatite formation in MC3T3-E1 osteoblasts on fibronectin coated self-assembled monolayers of alkanethiols with $\mathrm{CH}_{3}, \mathrm{OH}$, $\mathrm{COOH}$ and $\mathrm{NH}_{2}$ terminals, using FTIR spectroscopy. They have found that surface chemistry can affect integrin binding of the cell to the substrate even when utilising the same coating 
molecule. Sutherland et al [53] have also analysed proliferative effects in human keratinocytes, melanocytes, fibroblasts and myofibroblasts adherent to fibronectin, laminin, collagen and vitronectin with similar results to our work. 


\subsection{Spectroscopic Assays}

Figures 5 and 6 display the results of FTIRM and CRM measurements of HaCaT cells attached to gelatin coated substrates, spectra of the gelatin itself, and spectra of the coated substrate. Note that, as described previously, substrates for cell adhesion are coated by incubation with the solution of coating molecule for a period of time, and are then subsequently washed a number of times in PBS to remove the unbound molecule, as this can subsequently influence the cell behaviour by its presence in the extra-cellular medium. Gelatin has spectral features similar to the $\mathrm{HaCaT}$ cells because of its protein nature, but at the thicknesses employed here, these features are not visible. Similar results were observed in spectroscopic measurements of fibronectin and laminin coated substrates [54].

Gazi et al [55] have recently demonstrated that formalin fixation preserves most effectively the subcellular structure within the cell observed by SRFTIR spectroscopy, while O Faolain et al [56] have shown that shifts of up to $10 \mathrm{~cm}^{-1}$ are observable in FTIR spectra of formalinfixed versus fresh tissue, with reduction in the intensity of the $\mathrm{C}=\mathrm{O}$ band at $1398 \mathrm{~cm}^{-1}$. Other features associated with the presence of formalin within the Raman spectrum occur at 1041 $\mathrm{cm}^{-1}$ and $1492 \mathrm{~cm}^{-1}$ and can indicate formalin contamination of the sample [57], while fixation has been observed to produce peaks at $1490 \mathrm{~cm}^{-1}$ and to reduce the Amide I peak at $1637 \mathrm{~cm}^{-1}$ [56]. These features may occur as a result of protein unravelling or amide cross-linking induced by formalin fixation. No such features were observed in either our FTIR or Raman spectra indicating no formalin contamination in the cellular samples. However, the effect of formalin on the protein Amide regions of the spectra, due to formalin-induced amide crosslinking [57], has not yet been investigated in cellular species.

The FTIR spectral features of the HaCaT cells display strong Amide A and Amide B vibrations in the high wavenumber regions ( 3328 and $3129 \mathrm{~cm}^{-1}$ respectively) with strong phospholipid terminal $-\mathrm{CH}_{3}$ stretching vibrations (both symmetric in the region of $2875 \mathrm{~cm}^{-1}$ and antisymmetric in the region of $2960 \mathrm{~cm}^{-1}$ ) also visible. The Raman spectral features in this region are also dominated by $-\mathrm{CH}_{3}$ and $-\mathrm{CH}_{2}$ stretching modes (between 2900 and 2983 $\mathrm{cm}^{-1}$ ), with a weak Amide A vibration (in the region of $3070 \mathrm{~cm}^{-1}$ ) and $-\mathrm{CH}$ stretch (in the region of $2729 \mathrm{~cm}^{-1}$ ), and water contributions above $3070 \mathrm{~cm}^{-1}$. Moving to the fingerprint region, the FTIR spectra are strong in the Amide I (peaking at $1654 \mathrm{~cm}^{-1}$ ) Amide II (peaking 
at $1555 \mathrm{~cm}^{-1}$ ) and Amide III (region from at 1330 to $1200 \mathrm{~cm}^{-1}$ ) with lipid $\delta-\mathrm{CH}_{2}$ and $\delta-\mathrm{CH}_{3}$ contributions (in the region from 1467 to $1455 \mathrm{~cm}^{-1}$ ) and $-\mathrm{COO}^{-}$stretching vibrations (in the region from 1370 to $1400 \mathrm{~cm}^{-1}$ ). These bands overlap to some extent in the lower wavenumber region with the $-\mathrm{PO}_{2}^{-}$stretching vibration $\left(1090-1084 \mathrm{~cm}^{-1} ; 1230-1244 \mathrm{~cm}^{-1}\right)$, the C-O stretching vibration of RNA ribose $\left(1160 ; 1120 ; 1060 ; 1050 \mathrm{~cm}^{-1}\right)$, and the symmetric and anstisymmetric stretch of -CO-O-C (lipid, $\sim 1170$ and $\sim 1120 \mathrm{~cm}^{-1}$ ).

Raman spectra of HaCaT cells again display strong Amide I $\left(\sim 1681 \mathrm{~cm}^{-1}\right)$, Adenine/Guanine in plane ring modes superimposed on $\mathrm{CH} / \mathrm{CH}_{2}$ vibrations $\left(\sim 1457 \mathrm{~cm}^{-1}\right)$ and Amide III vibrations $\left(\sim 1230-1260 \mathrm{~cm}^{-1}\right)$. Lipid contributions from $-\mathrm{CH}_{2}$ and $-\mathrm{CH}_{3}$ stretching (1308-1398 $\left.\mathrm{cm}^{-1}\right)$ are strong, as are those from $-\mathrm{PO}_{2}^{-}$residues of DNA/RNA $\left(1056-1111,863-935 \mathrm{~cm}^{-1}\right.$ and $\left.783-847 \mathrm{~cm}^{-1}\right)$ and Phenylalanine ring breathing modes $\left(1003 \mathrm{~cm}^{-1}\right)$.

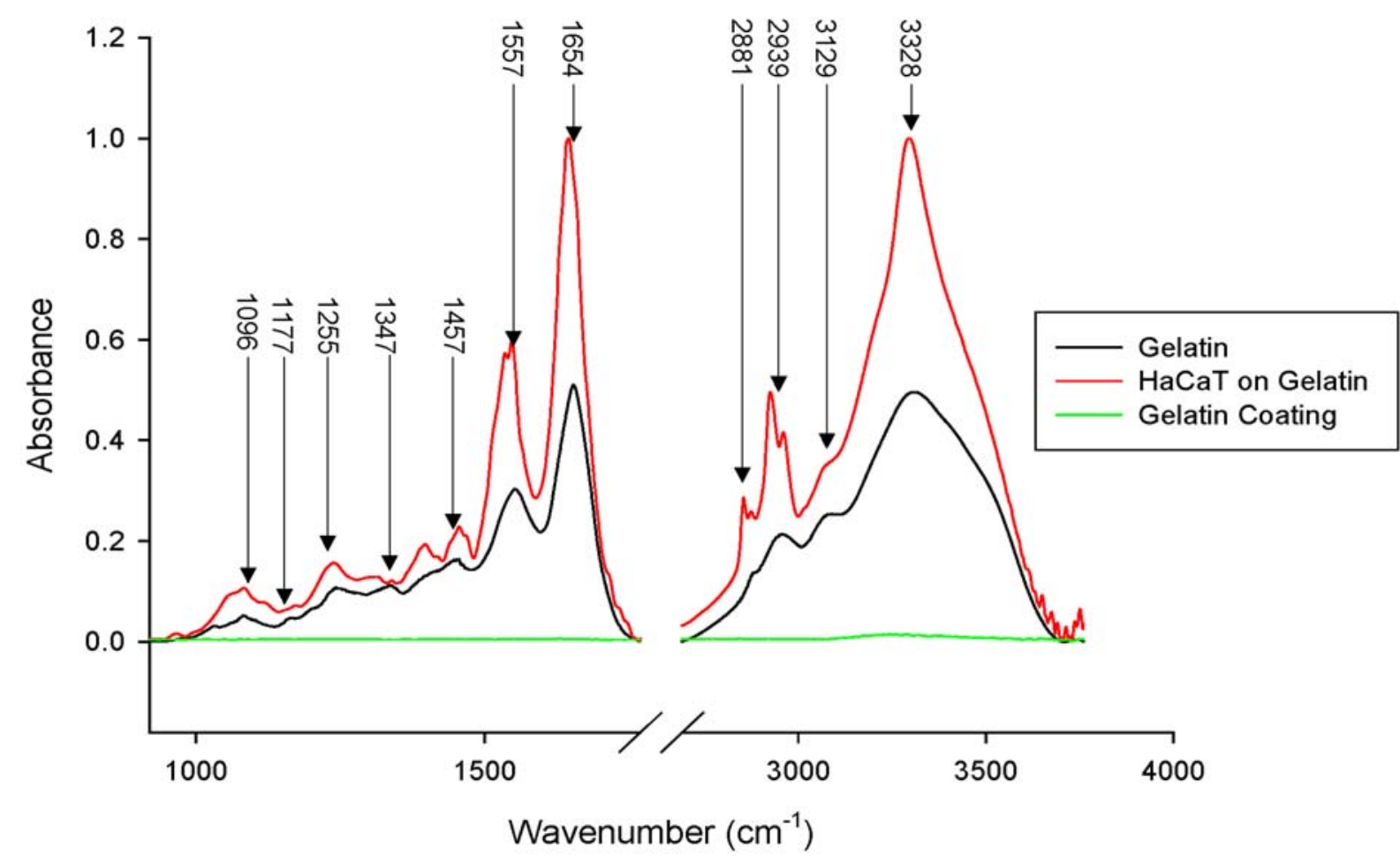

Figure 5. FTIR spectra of gelatin coated MirrIR slide with measured FTIR spectrum of gelatin and that of HaCaT cells grown on gelatin. 


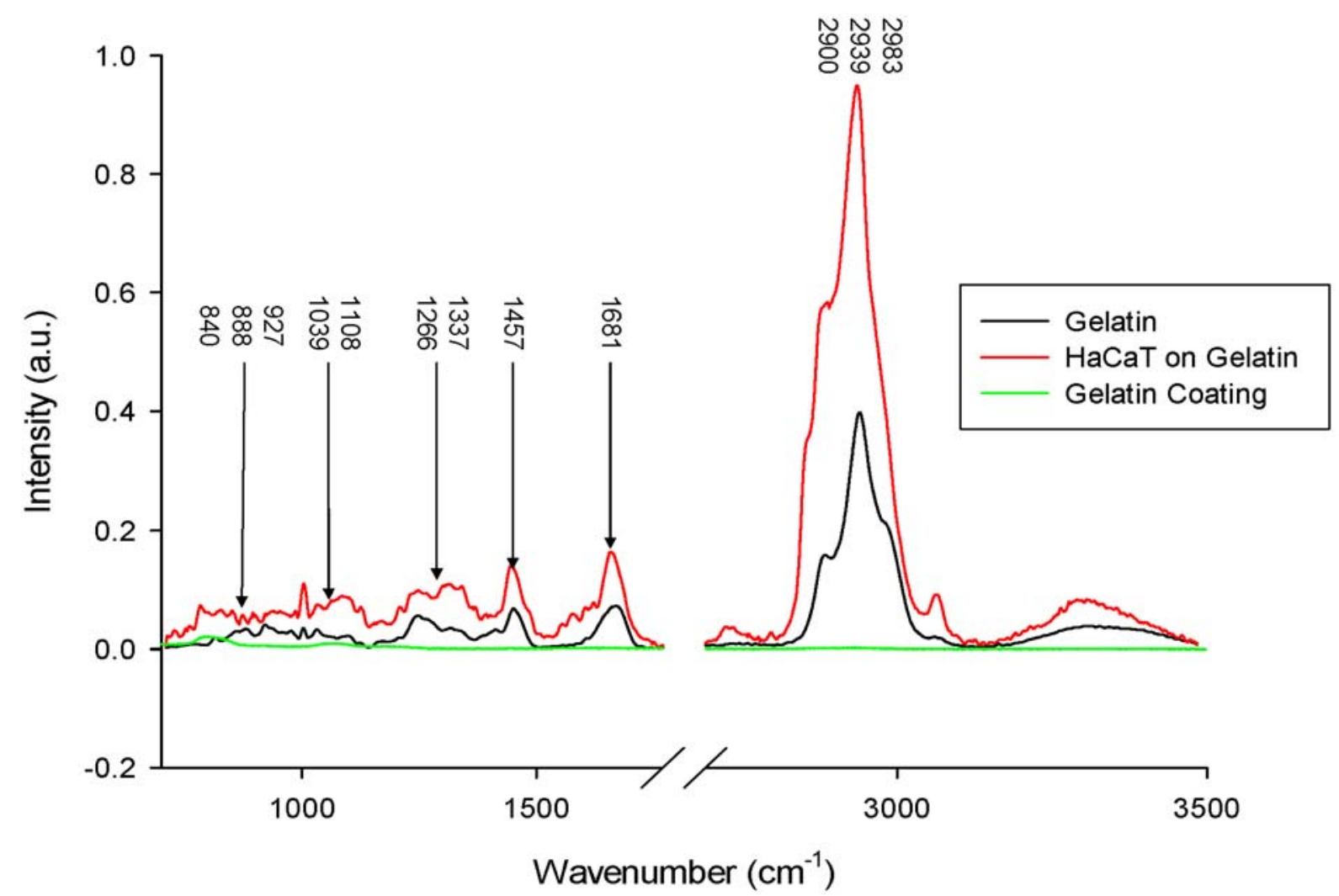

Figure 6. Raman spectra of gelatin coated quartz slide with measured Raman spectrum of gelatin and that of $\mathrm{HaCaT}$ cells grown on gelatin.

Results of spectroscopic measurements (in the fingerprint region) of $\mathrm{HaCaT}$ cells on coated spectroscopic substrates are shown in figures 7-9(b). Raman spectra were normalised to the CH band intensity at $2939 \mathrm{~cm}^{-1}$ (not shown). FTIR spectra are averages of 250 measurements, with normalisation to the Amide I band absorbance at $1654 \mathrm{~cm}^{-1}$. 


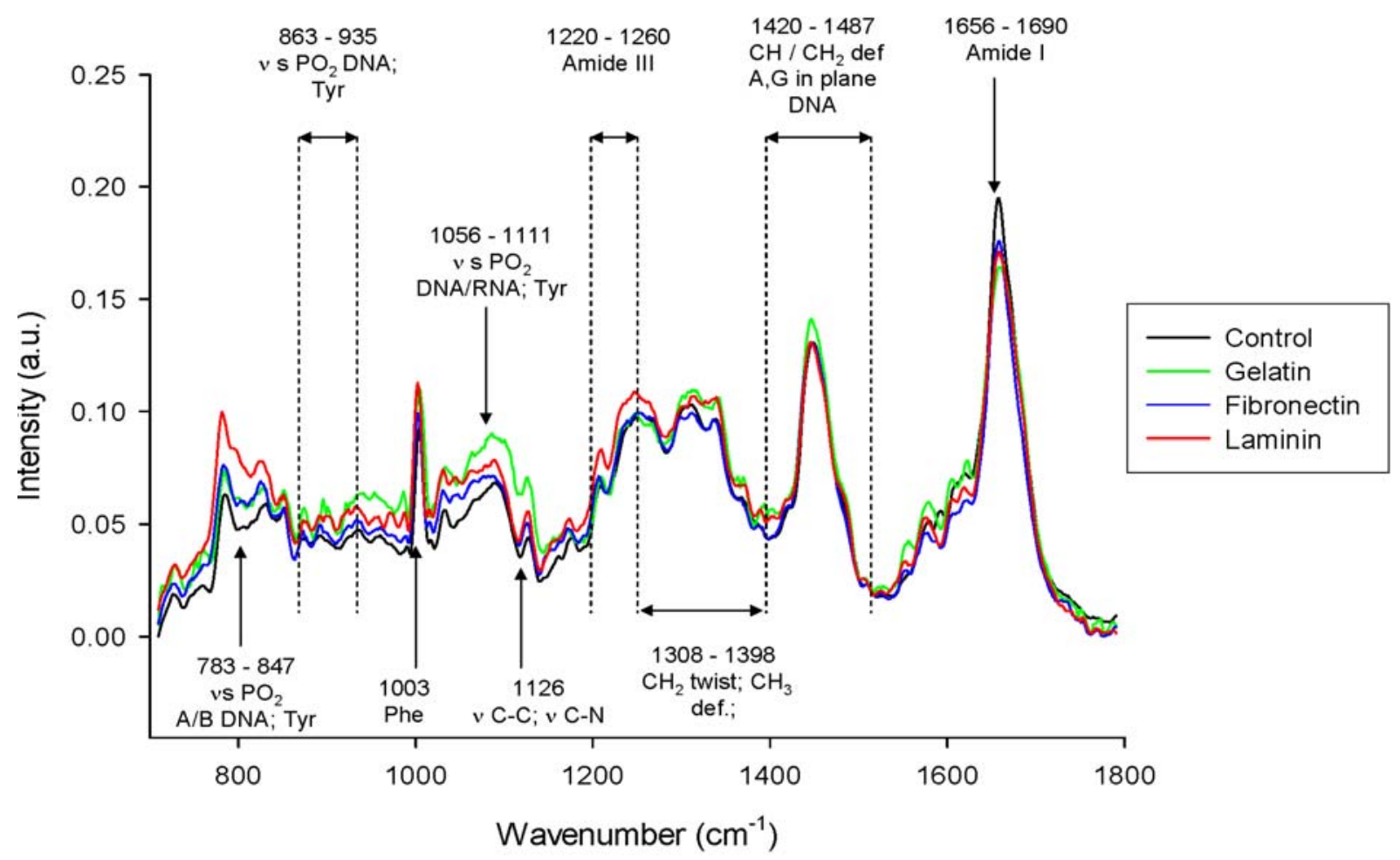

Figure 7. Raman spectra of $\mathrm{HaCaT}$ cells on coated spectroscopic substrates in the fingerprint region (700 to 1800 $\left.\mathrm{cm}^{-1}\right)$.

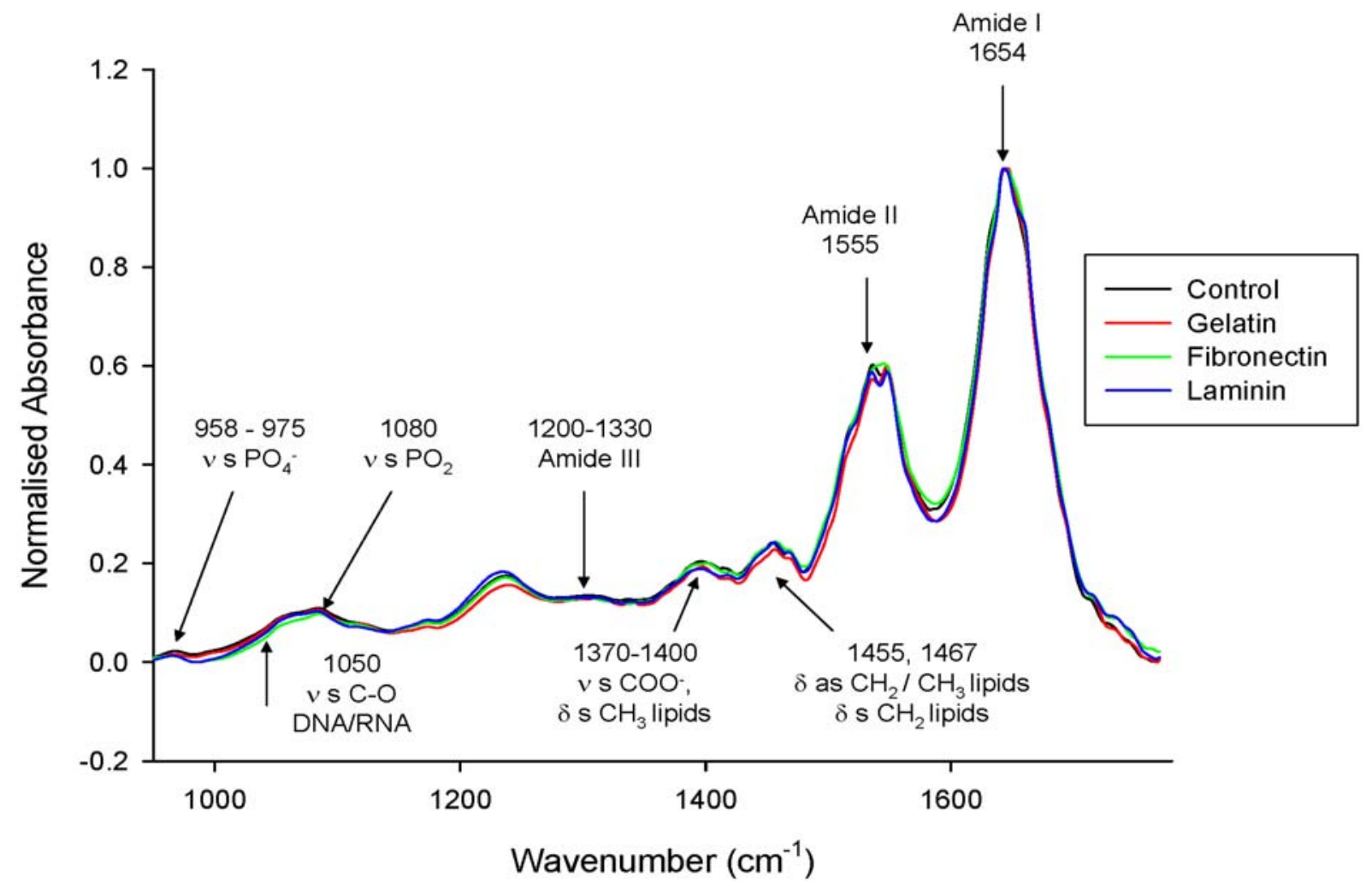

Figure 8. FTIR spectra of HaCaT cells on coated spectroscopic substrates in the fingerprint region (920 to 1770 $\left.\mathrm{cm}^{-1}\right)$. 


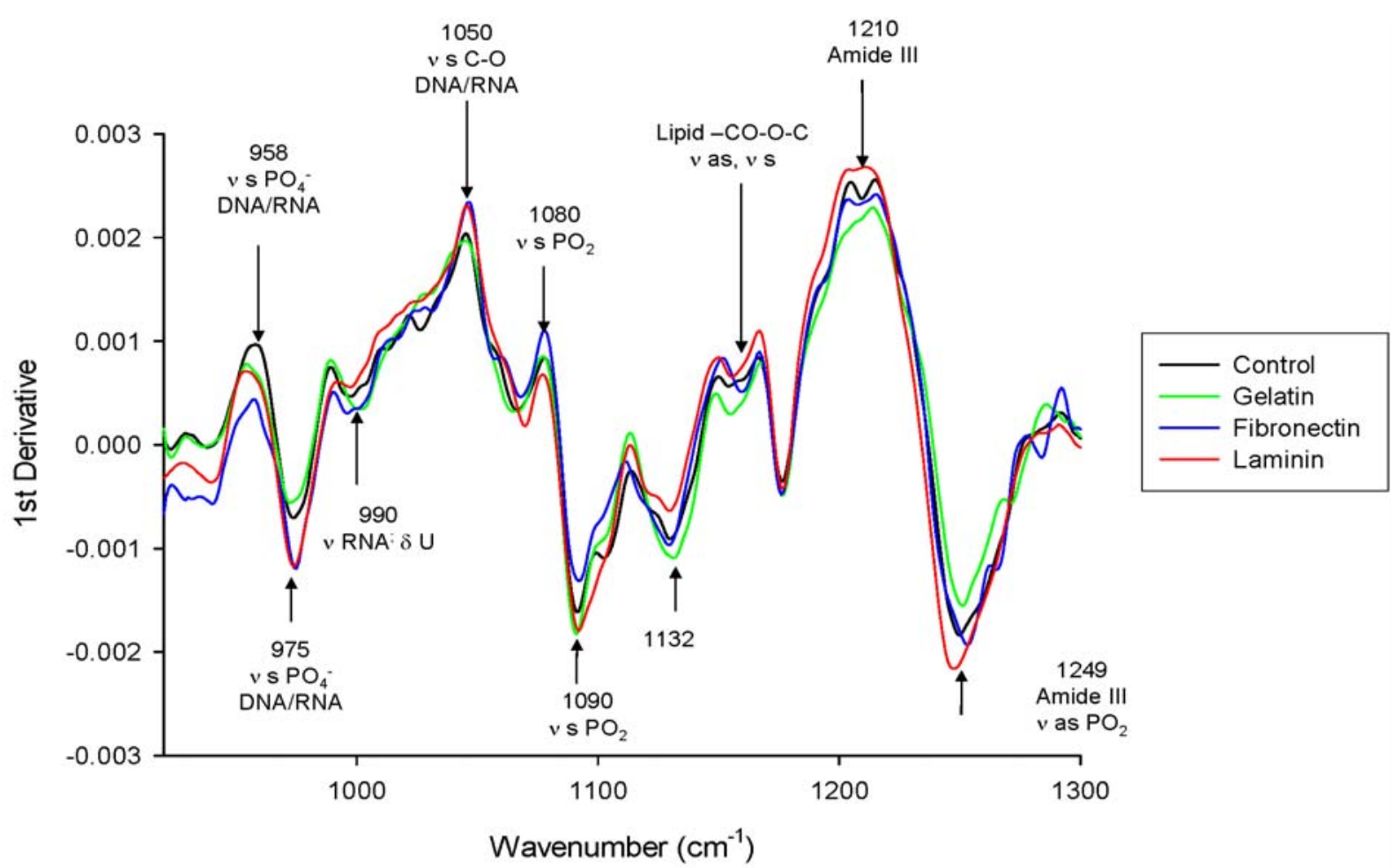

Figure 9(a). First Derivative FTIR spectra of HaCaT cells on coated spectroscopic substrates in the fingerprint region (920$\left.1300 \mathrm{~cm}^{-1}\right)$

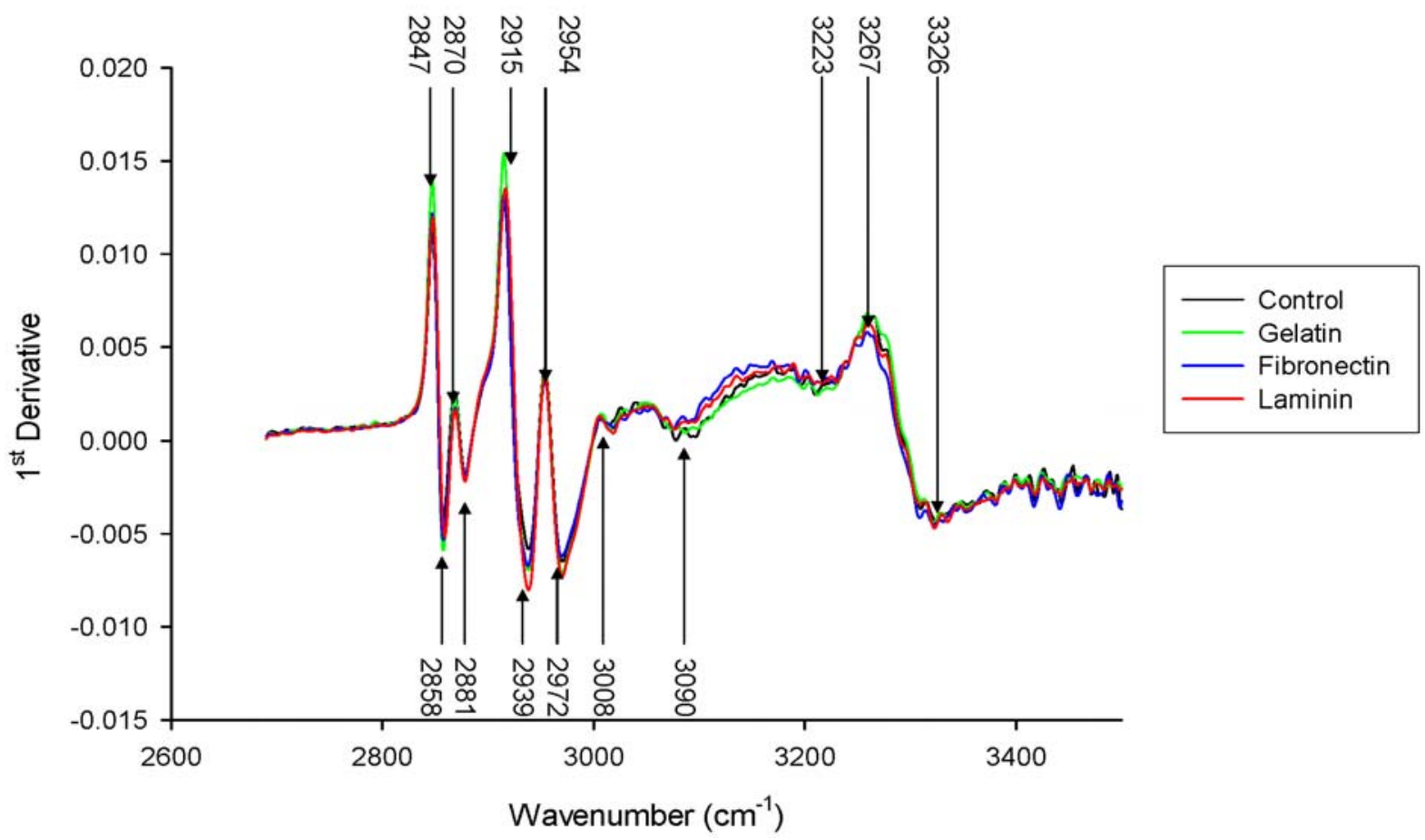

Figure 9(b). First Derivative FTIR spectra of HaCaT cells on coated spectroscopic substrates in the CH region (2690-3500 $\left.\mathrm{cm}^{-1}\right)$. 
The first derivative FTIR spectra exhibit shape changes in the HaCaT cell spectra in regions of the spectrum associated with nucleic acid, lipid and protein expression (respectively from 950 to $1090 \mathrm{~cm}^{-1}$, at 1070 and $1170 \mathrm{~cm}^{-1}$, and from $1200-1330 \mathrm{~cm}^{-1}$, with other changes in the lipid and protein regions from 1370-1467 $\mathrm{cm}^{-1}$ ). Such spectral changes have been seen recently in proliferating mammalian cells $[6,8]$. The correlation between cell viability (NR fluorescence) and FTIR spectral changes in the $\mathrm{HaCaT}$ cells attached to different substrates was investigated using calculations of band integral ratios from the raw spectra. This correlation is depicted in figure 10 for FTIR spectral measurements (where in this, and all subsequent, plots of band integral ratios, a straight line is overlaid as a guide for the eye to the inferred correlation). The integral of absorbance between 2850 and $3015 \mathrm{~cm}^{-1}$ has been taken as an estimate of the total lipid $-\mathrm{CH},-\mathrm{CH}_{2}$ and $-\mathrm{CH}_{3}$ bond vibration content (in the $\mathrm{CH}$ region, termed 'Lipid CH' here), while the integral of absorbance between 3129 and $3328 \mathrm{~cm}^{-1}$ has been taken as an estimate of the total protein Amide A and B vibration content (also in the $\mathrm{CH}$ region, termed 'Amide $\mathrm{AB}$ ' here), and the sum of the integrals of absorbance between 1084 and $1090 \mathrm{~cm}^{-1}$ and between 1230 and $1240 \mathrm{~cm}^{-1}$ have been taken as an estimate of total $\mathrm{PO}_{2}{ }^{-}$bond vibration content. There are some slight contributions from water in the IR spectra in the 3000-3500 $\mathrm{cm}^{-1}$ region, evident in figure 9(b), although these should be removed in the peak area ratio of Amide $\mathrm{AB}$ to Lipid $\mathrm{CH}$. A correlation between both the ratio of lipid to $\mathrm{PO}_{2}^{-}$band areas and the ratio of lipid to Amide A and B band integrals was observed. This may signify that the integrity of lipid, protein, and nucleic acid backbone are crucial to cell viability.

It has been found by Mourant et al [8], by means of fitting base sets to cellular FTIR spectra, that the ratio of RNA to lipid content and the ratio of protein to lipid content increase with increasing cellular proliferation. In the present study, RNA content was estimated using the integral of absorbance from 1710-1716 $\mathrm{cm}^{-1}$ (symmetric stretch of $\mathrm{C}=\mathrm{O}$ in RNA). Lipid content was estimated using an integral of the absorbance from 1370 to $1400 \mathrm{~cm}^{-1}\left(\mathrm{COO}^{-}\right.$ stretch and $-\mathrm{CH}_{3}$ symmetric bending in protein and lipids), and Amide I, Amide II and Amide III cumulative contributions were estimated using the integral of absorbance from 1630-1654 $\mathrm{cm}^{-1}, 1530-1550 \mathrm{~cm}^{-1}$ and $1200-1330 \mathrm{~cm}^{-1}$ respectively. 'Total Protein' was computed using a summation of the Amide I, II and III band integrals. These integrals were compared to quantitative estimates of cellular proliferative capacity from normalised $\mathrm{AB}$ fluorescence and are depicted in figure 11. The ratios for each of the absorbance integrals increase with increasing cellular proliferation as found by Mourant et al [8], with the most significant 
association between proliferation and the total protein to lipid content. Linear fits have been applied to each set of data as a means of examining the relative degree of association between each of the metrics and cellular proliferation, although in the case of both the Amide I to lipid ratio and the RNA to lipid ratio, this is better served by a $2^{\text {nd }}$ order polynomial fit. It is difficult to ascertain ratios indicative of RNA synthesis (both in FTIR and Raman spectra) because there are so many overlapping bands in this region of the spectrum. This may account for the large error bars seen in the spectral area ratios of RNA vs lipid.

Raman spectral changes are also observable in those parts of the fingerprint region associated with DNA and RNA $\mathrm{PO}_{2}^{-}\left(862-915 \mathrm{~cm}^{-1} ; 1056-1100 \mathrm{~cm}^{-1} ; 1212-1266\right)$, protein (Amide I, $1657-1690 \mathrm{~cm}^{-1}$; Amide III, 1212-1266) and lipid (1397-1452 $\left.\mathrm{cm}^{-1}\right)$. Increases in the regions associated with DNA and RNA, and protein, with decreases in those regions associated with lipid, were observed in cells with increased proliferation (figure 7), which have been noted previously [8]. Quantification of the correlation between the spectra and fluorescence measurements are shown in figures 12 and 13. It should be noted that the control points in each graph in each figure will overlap at 1 , and that the SE bars in the direction of each of the peak area integrals is not shown (although these are in all cases less than 5\% in either direction). The lipid (estimated from the integral from 2870 to $2975 \mathrm{~cm}^{-1}$ ) to Amide AB (estimated from the integral from 3048 to $3087 \mathrm{~cm}^{-1}$ ) and $-\mathrm{PO}_{2}^{-}$(estimated from the integral of intensity from $\left.862-915 \mathrm{~cm}^{-1}\right)$ to Lipid band integral ratios $\left(1396-1452 \mathrm{~cm}^{-1}\right)$ were found to increase with increasing NR fluorescence (cell viability), as demonstrated in figure 12. A correlation was also observed between the total protein (estimated via the summation of the area of the Amide I and Amide III band integrals) to lipid ratio, the $-\mathrm{PO}_{2}{ }^{-}$to Amide I ratio, the $-\mathrm{PO}_{2}^{-}$(due to RNA and estimated from the integral from 783 to $848 \mathrm{~cm}^{-1}$ ) to lipid (1397-1452 $\mathrm{cm}^{-1}$ ) ratio and the cellular proliferation as measured by AB fluorescence (figure 13). Similar trends have been observed previously by Short et al [6], where increases in protein and decreases in lipid were observed in proliferating cells, with decreases in RNA and increases in DNA between plateau and exponential phase cells. It is difficult to elucidate spectral changes associated with proliferative effects from Raman spectra, using peak area ratios, due to the large degree of spectral overlap between subcomponents (nucleic acid, protein, lipid etc.) within the spectrum [8]. This difficulty may be lessened through careful choice of spectral intervals for integration, as was the approach adopted here. The spectral changes observed here are consistent with those previously observed in experiments utilising spectral decomposition [8], and as such support the approach adopted here. 


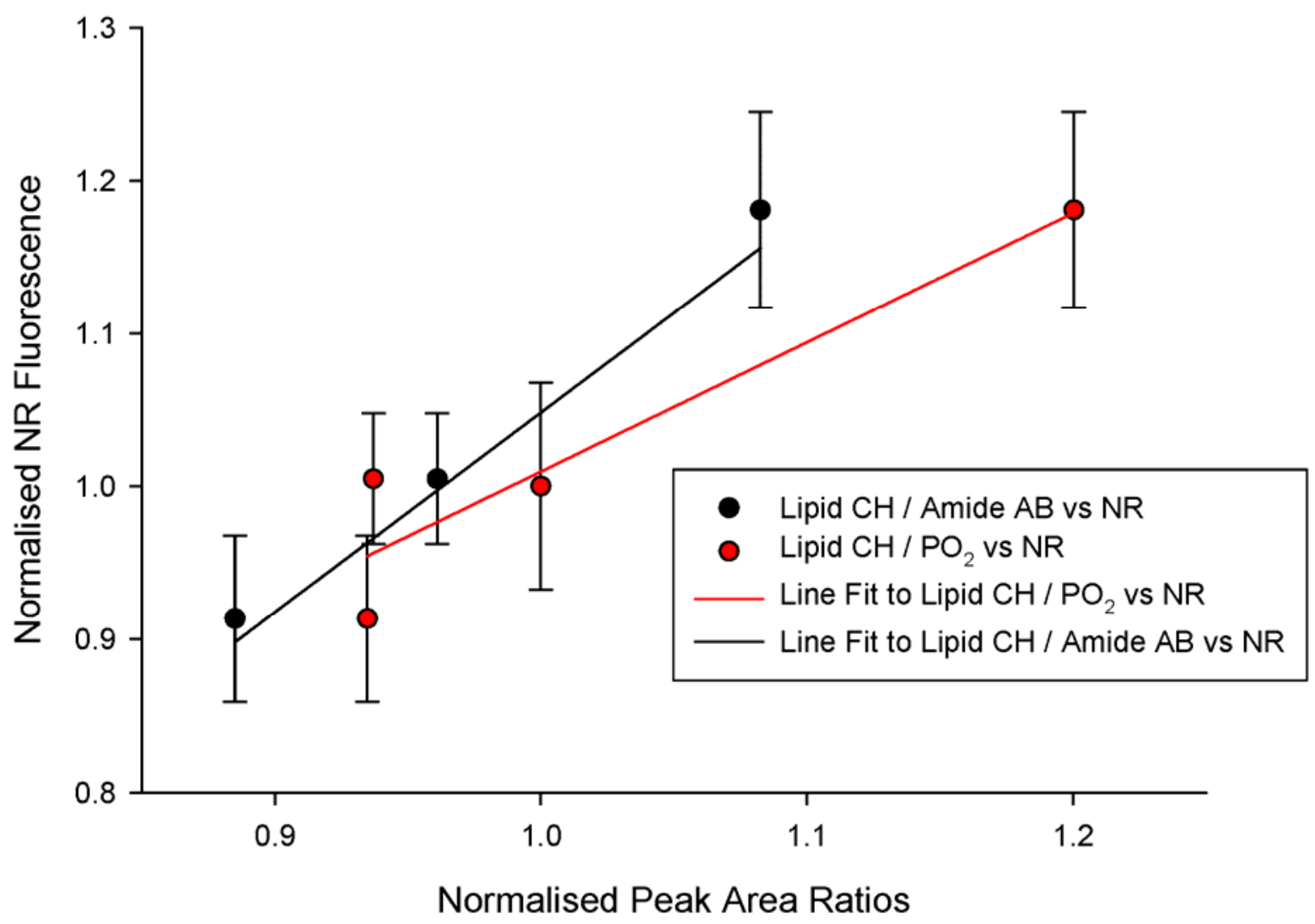

Figure 10.Correlation of various FTIR band integrals (as described in the text) to NR fluorescence (cell viability). All measurements are normalised to the corresponding control measurement. 


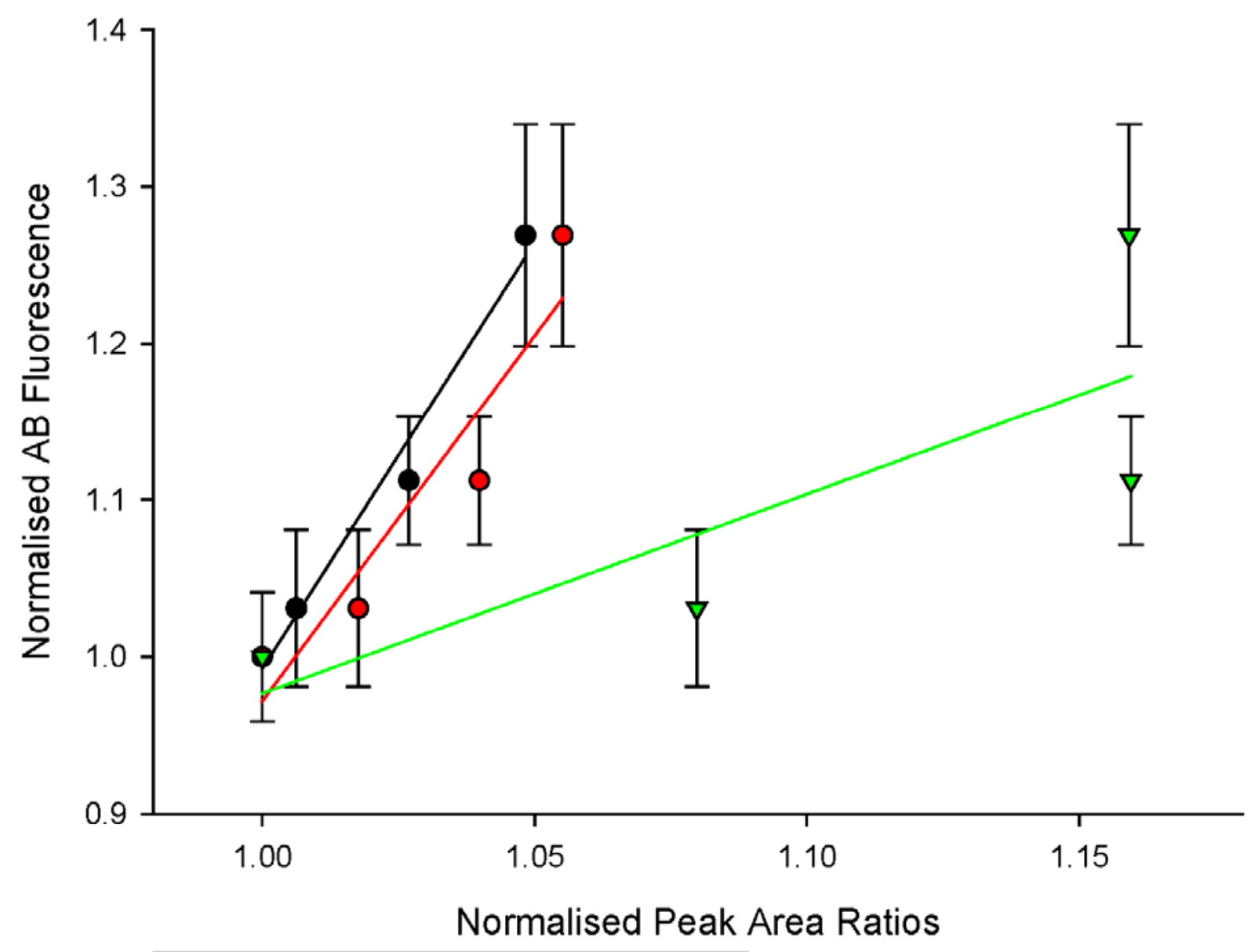

- Total Protein / Lipid vs AB

- Amide I / Lipid vs AB

$\nabla$ RNA / Lipid vs AB

Line Fit Total Protein / Lipid vs AB

Line Fit Amide I / Lipid vs AB

Line Fit RNA / Lipid vs $A B$

Figure 11. Correlation of various FTIR band integrals (as described in the text) to AB fluorescence (proliferative capacity).

All measurements are normalised to the corresponding control measurement. 


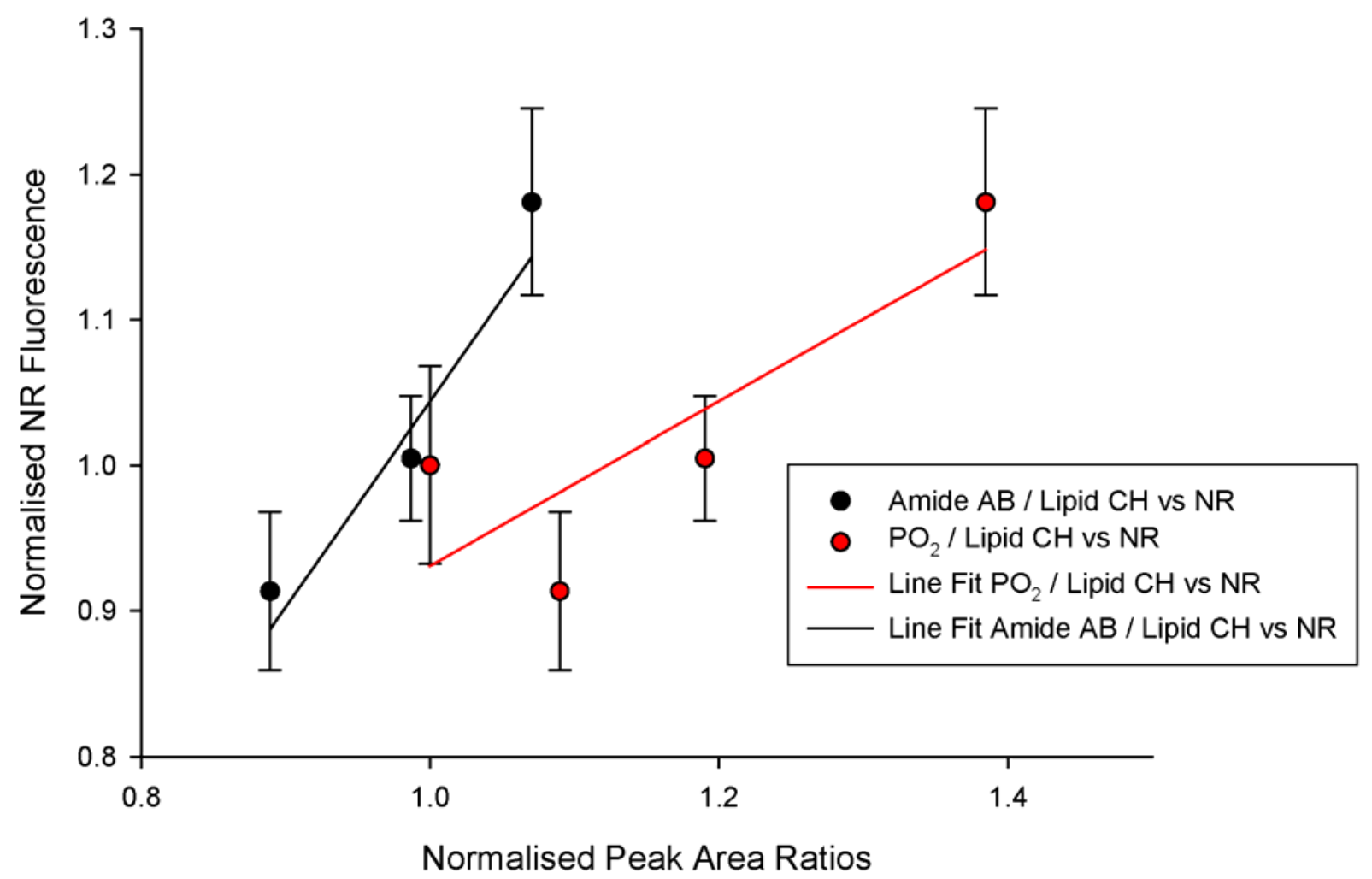

Figure 12. Correlation of various Raman band integrals (as described in the text) to NR fluorescence (cell viability) All measurements are normalised to the corresponding control measurement.

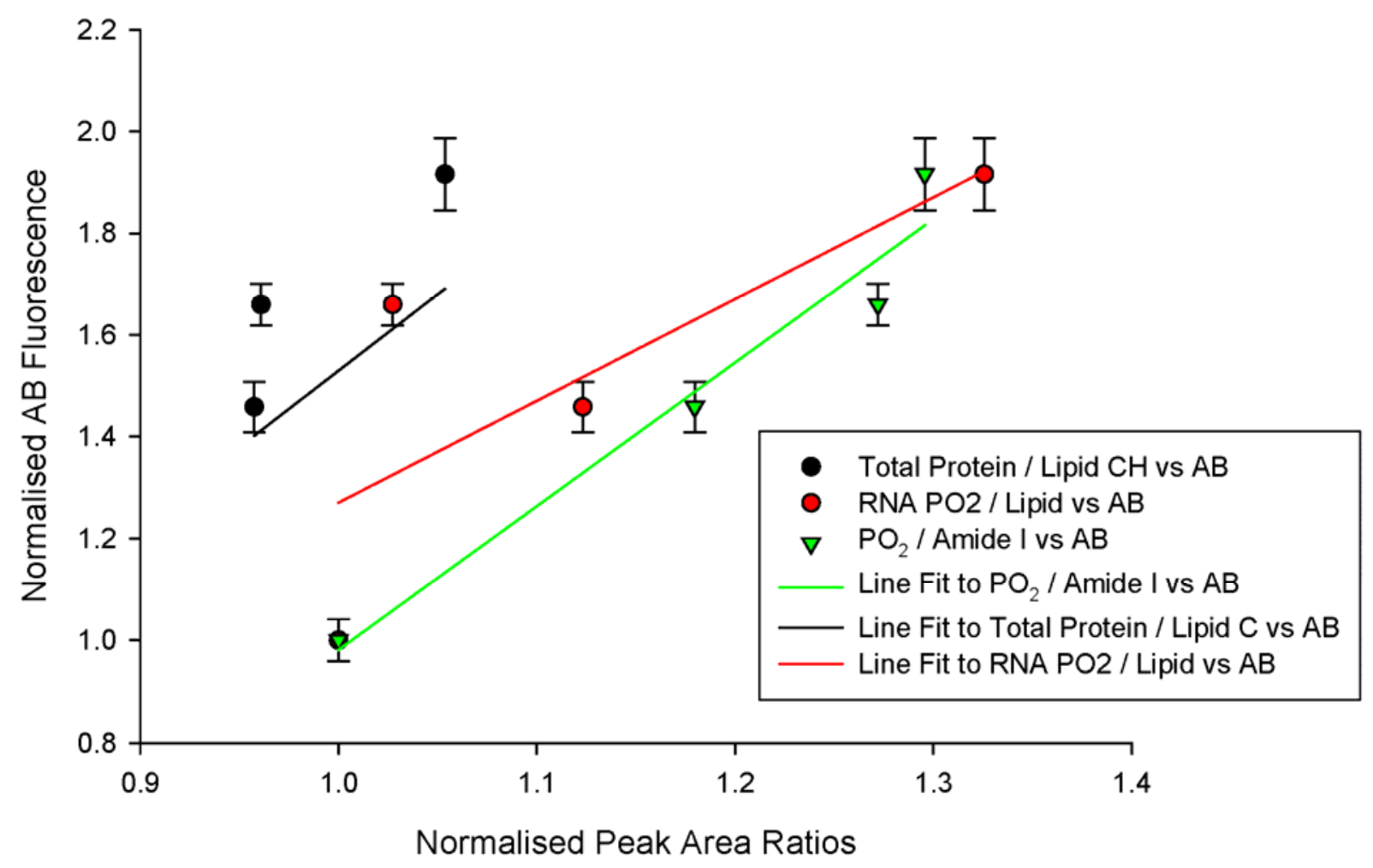

Figure 13. Correlation of various Raman band integrals (as described in the text) to AB fluorescence (proliferative capacity) All measurements are normalised to the corresponding control measurement. 


\section{Conclusion}

Cell culture for spectroscopic measurements has not previously been performed with correction for the effects cell attachment has on cellular physiology. Recently it has been demonstrated in the literature that these effects can be expressed in the cell at the level of genomic regulation, thus contributing to very fundamental changes in cellular physiology, ultimately resulting in unknown adjustments to cellular proliferation, motility and, in some cases, phenotype [17-23]. In this work we have demonstrated that measurements of cellular proliferation and viability on coated spectroscopic substrates can be correlated with spectral changes induced by adjustments to cell physiology when cultured on the different coatings. These measurements demonstrate that the interaction of the cell with coated spectroscopic substrates can influence the spectroscopic measurement made using vibrational spectroscopy. Ultimately this implies that spectroscopic measurements made using Raman and IR spectroscopy, if they are to be used together to characterize cellular interaction with toxic agents, etc., should utilise a coating, such as gelatin, which harmonises the cell interaction with the spectroscopic substrate, such that the measurements are intercomparable and complementary. The measurements also demonstrate that vibrational spectroscopy can probe the results of cellular interactions occuring at genomic level, which can be significant to the development of these modalities in the future.

\section{Acknowledgements}

The authors acknowledge funding through the Dublin Institute of Technology TERS 2004 scheme. The Focas Institute, DIT has been established under the Irish HEA Programme for Research in Third Level Institutions, Cycle 1 (1999-2001). 


\section{References}

1. Gaudenzi S, Pozzi, D., Toro, P., Silvestri, I., Morrone, S., Castellano, C. Cell apoptosis specific marker found by Fourier Transform Infrared Spectroscopy. Spectroscopy 2004;18:415-422.

2. Notingher I, Selvakumaran J, Hench LL. New detection system for toxic agents based on continuous spectroscopic monitoring of living cells. Biosens Bioelectron 2004;20(4):780-9.

3. Uzunbajakava N, Lenferink A, Kraan Y, Volokhina E, Vrensen G, Greve J, et al. Nonresonant confocal Raman imaging of DNA and protein distribution in apoptotic cells. Biophys J 2003;84(6):3968-81.

4. Notingher I, Verrier S, Haque S, Polak JM, Hench LL. Spectroscopic study of human lung epithelial cells (A549) in culture: living cells versus dead cells. Biopolymers 2003;72(4):230-40.

5. Holman HYN, Martin, M.C., Blakely, E.A., Bjornstad, K., McKinney, W.R. IR spectroscopic characteristics of cell cycle and cell death probed by synchrotron radiation based fourier transform IR spectromicroscopy. Biopolymers (Biospectroscopy) 2000;57:329-335.

6. Short KW, Carpenter, S., Freyer, J. P., and Mourant, J. R. Raman Spectroscopy Detects Biochemical Changes Due to Proliferation in Mammalian Cell Cultures. Biophysical Journal 2005;88:4274-4288.

7. Mourant JR, Canpolat M, Brocker C, Esponda-Ramos O, Johnson TM, Matanock A, et al. Light scattering from cells: the contribution of the nucleus and the effects of proliferative status. J Biomed Opt 2000;5(2):131-7.

8. $\quad$ Mourant JR, Yamada YR, Carpenter S, Dominique LR, Freyer JP. FTIR spectroscopy demonstrates biochemical differences in mammalian cell cultures at different growth stages. Biophys J 2003;85(3):1938-47.

9. Matthaus C, Boydston-White S, Miljkovic M, Romeo M, Diem M. Raman and infrared microspectral imaging of mitotic cells. Appl Spectrosc 2006;60(1):1-8.

10. Notingher I, Bisson I, Bishop AE, Randle WL, Polak JM, Hench LL. In situ spectral monitoring of mRNA translation in embryonic stem cells during differentiation in vitro. Anal Chem 2004;76(11):3185-93.

11. Notingher I, Jell G, Lohbauer U, Salih V, Hench LL. In situ non-invasive spectral discrimination between bone cell phenotypes used in tissue engineering. J Cell Biochem 2004;92(6):1180-92.

12. Holman HYN, Bjornstad, K., Mc Namara, M.P., M.C. Martin, W.R. McKinney, E.A. Blakely. Synchrotron infrared spectromicroscopy as a novel bioanalytical microprobe for individual living cells: cytotoxicity considerations. J Biomed Opt 2002;7(3):417-424.

13. Notingher I, Verrier, S., Romanska, H., Bishop, A.E., Polak, J.M., Hench, L.L. In situ characterisation of living cells by Raman spectroscopy. Spectroscopy - Int. J. 2002;16(2):43-51.

14. Puppels GJ, Olminkhof JH, Segers-Nolten GM, Otto C, de Mul FF, Greve J. Laser irradiation and Raman spectroscopy of single living cells and chromosomes: sample degradation occurs with $514.5 \mathrm{~nm}$ but not with $660 \mathrm{~nm}$ laser light. Exp Cell Res 1991;195(2):361-7.

15. Ramser K, Bjerneld, E.J., Fant, C., Kall, M. Importance of substrate and photo-induced effects in Raman spectroscopy of single functional erythrocytes. Journal of Biomedical Optics 2003;8(2):173-178.

16. Keselowsky BG, Collard DM, Garcia AJ. Integrin binding specificity regulates biomaterial surface chemistry effects on cell differentiation. Proc Natl Acad Sci U S A 2005;102(17):5953-7.

17. Gaudet C, Marganski WA, Kim S, Brown CT, Gunderia V, Dembo M, et al. Influence of type I collagen surface density on fibroblast spreading, motility, and contractility. Biophys J 2003;85(5):3329-35.

18. Keselowsky BG, Collard DM, Garcia AJ. Surface chemistry modulates focal adhesion composition and signaling through changes in integrin binding. Biomaterials 2004;25(28):5947-54.

19. Garcia AJ, Vega MD, Boettiger D. Modulation of cell proliferation and differentiation through substrate-dependent changes in fibronectin conformation. Mol Biol Cell 1999;10(3):785-98.

20. Allen LT, Tosetto M, Miller IS, O'Connor DP, Penney SC, Lynch I, et al. Surface-induced changes in protein adsorption and implications for cellular phenotypic responses to surface interaction. Biomaterials 2006;27(16):3096-108.

21. Brodbeck WG, Shive MS, Colton E, Nakayama Y, Matsuda T, Anderson JM. Influence of biomaterial surface chemistry on the apoptosis of adherent cells. J Biomed Mater Res 2001;55(4):661-8.

22. Shen M, Horbett TA. The effects of surface chemistry and adsorbed proteins on monocyte/macrophage adhesion to chemically modified polystyrene surfaces. J Biomed Mater Res 2001;57(3):336-45.

23. Redey SA, Nardin M, Bernache-Assolant D, Rey C, Delannoy P, Sedel L, et al. Behavior of human osteoblastic cells on stoichiometric hydroxyapatite and type A carbonate apatite: role of surface energy. $\mathrm{J}$ Biomed Mater Res 2000;50(3):353-64. 
24. Boukamp P, Petrussevska RT, Breitkreutz D, Hornung J, Markham A, Fusenig NE. Normal keratinization in a spontaneously immortalized aneuploid human keratinocyte cell line. J Cell Biol 1988;106(3):761-71.

25. Boudreau NJ, Jones, P.L. Extracellular matrix and integrin signalling : the shape of things to come. Biochem. J. 1999;339:481-488.

26. Colognato H, Yurchenco PD. Form and function: the laminin family of heterotrimers. Dev Dyn 2000;218(2):213-34.

27. Frushour BG, Koenig JL. Raman scattering of collagen, gelatin, and elastin. Biopolymers 1975;14(2):379-91.

28. Mousia Z, Farhat IA, Pearson M, Chesters MA, Mitchell JR. FTIR microspectroscopy study of composition fluctuations in extruded amylopectin-gelatin blends. Biopolymers 2001;62(4):208-18.

29. O'Brien J, Wilson, I., Orton T., Pognan, P. Investigation of the Alamar Blue (resazurin) fluorescent dye for the assessment of mammalian cell cytotoxicity. Eur. J. Biochem. 2000;267:5421-5426.

30. Slaughter MR, Bugelski, P.J., O' Brien, P.J. Evaluation of Alamar Blue reduction for the in-vitro assay of hepatocyte toxicity. Toxicology In Vitro 1999;13:567-569.

31. Borenfreund E, Puerner, J A. A simple quantitatve procedure using monolayer culture for cytotoxicity assays. J. Tissue Cult. Methods 1984;9:7-9.

32. Mammone T, Gan D, Collins D, Lockshin RA, Marenus K, Maes D. Successful separation of apoptosis and necrosis pathways in HaCaT keratinocyte cells induced by UVB irradiation. Cell Biol Toxicol 2000;16(5):293-302.

33. Zhang SZ, Lipsky MM, Trump BF, Hsu IC. Neutral red (NR) assay for cell viability and xenobioticinduced cytotoxicity in primary cultures of human and rat hepatocytes. Cell Biol Toxicol 1990;6(2):219-34.

34. Ahmad H, Saleemuddin M. A Coomassie blue-binding assay for the microquantitation of immobilized proteins. Anal Biochem 1985;148(2):533-41.

35. Liebsch HM, Spielmann H. Balb/c 3T3 cytotoxicity test. Methods Mol Biol 1995;43:177-87.

36. Ní Shúilleabháin S, Mothersill, C., Sheehan, D., O’Brien, N.M., O’ Halloran, J., Van Pelt, F.N.A.M., Davoren M. In vitro cytotoxicity testing of three zinc metal salts using established fish cell lines. Toxicol In Vitro 2004;18(3):365-376.

37. Murali Krishna C, Kegelaer G, Adt I, Rubin S, Kartha VB, Manfait M, et al. Characterisation of uterine sarcoma cell lines exhibiting MDR phenotype by vibrational spectroscopy. Biochim Biophys Acta 2005;1726(2):160-7.

38. Nijssen A, Bakker Schut TC, Heule F, Caspers PJ, Hayes DP, Neumann MH, et al. Discriminating basal cell carcinoma from its surrounding tissue by Raman spectroscopy. J Invest Dermatol 2002;119(1):64-9.

39. Synytsya A, Alexa P, Besserer J, De Boer J, Froschauer S, Gerlach R, et al. Raman spectroscopy of tissue samples irradiated by protons. Int J Radiat Biol 2004;80(8):581-91.

40. Edwards HGM, Carter, E.A. Biological Applications of Raman Spectroscopy. Infrared and Raman Spectroscopy of Biological Materials (Practical Spectroscopy) 2000;Gremlich, H.U., and Yan, B. eds:421-477.

41. Puppels GJ, Garritsen HS, Segers-Nolten GM, de Mul FF, Greve J. Raman microspectroscopic approach to the study of human granulocytes. Biophys J 1991;60(5):1046-56.

42. Gault N, Lefaix JL. Infrared microspectroscopic characteristics of radiation-induced apoptosis in human lymphocytes. Radiat Res 2003;160(2):238-50.

43. Gault N, Poncy JL, Lefaix JL. [Radiation-induced apoptosis: a new approach using infrared microspectroscopy]. Can J Physiol Pharmacol 2004;82(1):38-49.

44. Gault N, Rigaud O, Poncy JL, Lefaix JL. Infrared microspectroscopy study of gamma-irradiated and $\mathrm{H}(2) \mathrm{O}(2)$-treated human cells. Int J Radiat Biol 2005;81(10):767-779.

45. Zellmer S, Zimmermann I, Selle C, Sternberg B, Pohle W, Lasch J. Physicochemical characterisation of human stratum corneum lipid liposomes. Chem Phys Lipids 1998;94(1):97-108.

46. Evis Z, Sato M, Webster TJ. Increased osteoblast adhesion on nanograined hydroxyapatite and partially stabilized zirconia composites. J Biomed Mater Res A 2006.

47. Rouahi M, Gallet O, Champion E, Dentzer J, Hardouin P, Anselme K. Influence of hydroxyapatite microstructure on human bone cell response. J Biomed Mater Res A 2006.

48. Zhu X, Eibl O, Scheideler L, Geis-Gerstorfer J. Characterization of nano hydroxyapatite/collagen surfaces and cellular behaviors. J Biomed Mater Res A 2006.

49. Chun J, Auer KA, Jacobson BS. Arachidonate initiated protein kinase C activation regulates HeLa cell spreading on a gelatin substrate by inducing F-actin formation and exocytotic upregulation of beta 1 integrin. $\mathrm{J}$ Cell Physiol 1997;173(3):361-70.

50. Bill HM, Knudsen B, Moores SL, Muthuswamy SK, Rao VR, Brugge JS, et al. Epidermal growth factor receptor-dependent regulation of integrin-mediated signaling and cell cycle entry in epithelial cells. Mol Cell Biol 2004;24(19):8586-99.

51. Putnins EE, Firth JD, Lohachitranont A, Uitto VJ, Larjava H. Keratinocyte growth factor (KGF) promotes keratinocyte cell attachment and migration on collagen and fibronectin. Cell Adhes Commun 1999;7(3):211-21. 
52. Doornaert B, Leblond V, Planus E, Galiacy S, Laurent VM, Gras G, et al. Time course of actin cytoskeleton stiffness and matrix adhesion molecules in human bronchial epithelial cell cultures. Exp Cell Res 2003;287(2):199-208.

53. Sutherland J, Denyer M, Britland S. Motogenic substrata and chemokinetic growth factors for human skin cells. J Anat 2005;207(1):67-78

54. Brumfeld V, Werber MM. Studies on fibronectin and its domains. II. Secondary structure and spatial configuration of fibronectin and of its domains. Arch Biochem Biophys 1993;302(1):134-43.

55. Gazi E, Dwyer, J., Lockyer, N.P., Miyan, J., Gardner, P., Hart, C., Brown, M., Clarke, N. W. Fixation Protocols for Subcellular Imaging by Synchrotron-Based Fourier Transform Infrared Microspectroscopy.

Biopolymers 2005;77:18-30.

56. O Faolain E, Hunter MB, Byrne JM, Kelehan P, McNamara M, Byrne HJ, et al. A study examining the effects of tissue processing on human tissue sections using vibrational spectroscopy. Vibrational Spectroscopy 2005;38(1-2):121-127.

57. Krishna CM, Sockalingum GD, Kurien J, Rao L, Venteo L, Pluot M, et al. Micro-Raman spectroscopy for optical pathology of oral squamous cell carcinoma. Appl Spectrosc 2004;58(9):1128-35. 